\title{
Community structure and biogeography of shore fishes in the Gulf of Aqaba, Red Sea
}

Received: 2 April 2001 / Received in revised form: 2 November 2001 / Accepted: 2 November 2001 / Published online: 24 January 2002 C) Springer-Verlag and AWI 2002

\begin{abstract}
Shore fish community structure off the Jordanian Red Sea coast was determined on fringing coral reefs and in a seagrass-dominated bay at $6 \mathrm{~m}$ and $12 \mathrm{~m}$ depths. A total of 198 fish species belonging to 121 genera and 43 families was recorded. Labridae and Pomacentridae dominated the ichthyofauna in terms of species richness and Pomacentridae were most abundant. Neither diversity nor species richness was correlated to depth. The abundance of fishes was higher at the deep reef slope, due to schooling planktivorous fishes. At $12 \mathrm{~m}$ depth abundance of fishes at the seagrass-dominated site was higher than on the coral reefs. Multivariate analysis demonstrated a strong influence on the fish assemblages by depth and benthic habitat. Fish species richness was positively correlated with hard substrate cover and habitat diversity. Abundance of corallivores was positively linked with live hard coral cover. The assemblages of fishes were different on the shallow reef slope, deep reef slope and seagrass meadows. An analysis of the fish fauna showed that the Gulf of Aqaba harbours a higher species richness than previously reported. The comparison with fish communities on other reefs around the Arabian Peninsula and Indian Ocean supported the recognition of an Arabian subprovince within the Indian Ocean. The affinity of the Arabian Gulf ichthyofauna to the Red Sea is not clear.
\end{abstract}

Keywords Community structure $\cdot$ Coral reef $\cdot$ Red Sea Seagrass meadow $\cdot$ Shore fishes

Communicated by H.-D. Franke

M.A. Khalaf (

Marine Science Station, PO Box 195 Aqaba, Jordan

e-mail: maroof@ju.edu.jo

Tel.: +962-3-2015144, Fax: +962-3-2013674

M. Kochzius ( $\square)$

Centre for Tropical Marine Ecology (ZMT), Fahrenheitstrasse 6, 28359 Bremen, Germany

e-mail: kochzius@uni-bremen.de

Tel.: +49-421-2380057, Fax: +49-421-2380030

\section{Introduction}

Coral reefs are one of the most complex marine ecosystems in which fish communities reach their highest degree of diversity (Harmelin-Vivien 1989). Morphological properties and the geographical region of the coral reef determine the structure of the fish assemblages (Sale 1980; Thresher 1991; Williams 1991). The ichthyofauna of coral reefs can be linked to varying degrees with adjacent habitats (Parrish 1989) such as seagrass meadows (Ogden 1980; Quinn and Ogden 1984; Roblee and Ziemann 1984; Kochzius 1999), algal beds (Rossier and Kulbicki 2000) and mangroves (Birkeland 1985; Thollot 1992).

Although the Red Sea ichthyofauna is taxonomically quite well known compared with other parts of the tropical Indo-Pacific Ocean, the community structure of shore fishes has been less well investigated. To date more than 1,280 fish species are known from the Red Sea (Baranes and Golani 1993; Goren and Dor 1994; Randall 1994; Khalaf et al. 1996). Ichthyological research in the Red Sea dates back more than 200 years to the collections and descriptions of fishes by Peter Forsskål (Klausewitz 1964; Nielsen 1993). Despite a long tradition of taxonomic work since then (e.g. Forsskål 1775; Klunzinger 1884), as well as biosociological and ecological studies on certain families, such as damselfish (Pomacentridae) (e.g. Fishelson et al. 1974; Fricke 1977; Ormond et al. 1996) and butterflyfish (Chaetodontidae) (e.g. BouchonNavaro 1980; Bouchon-Navaro and Bouchon 1989; Roberts et al. 1992), surprisingly few studies have been published on the general community structure of Red Sea shore fishes (Ben-Tuvia et al. 1983; Rilov and Benayahu 2000). Other investigation deal with fish communities on artificial reefs (Rilov and Benayahu 1998; Golani and Diamant 1999) or give species lists for certain areas (Clark et al. 1968; Tortonese 1983).

Shallow-water habitats along the Jordanian Red Sea coast are fringing coral reefs and seagrass meadows. The coral reefs of the Jordanian coast have been studied in detail by Mergner and Schuhmacher (Mergner and 
Schuhmacher 1974, 1981; Mergner 1979, 2001). Several studies on the autecology (e.g. Harmelin-Vivien and Bouchon-Navaro 1981; Wahbeh and Ajiad 1985a, b) and population ecology (e.g. Bouchon-Navaro and HarmelinVivien 1981; Bouchon-Navaro 1986) of fishes were conducted along the Jordanian coastline of the Gulf of Aqaba, but no study using a synecological approach has been conducted to date.

Coral reefs are under threat on a global scale (Bryant et al. 1998; Hoeg-Guldberg 1999; Souter and Lindén 2000) and under high human impact in the Gulf of Aqaba, because of pollution (Walker and Ormond 1982; Abu-Hilal 1987; Abu-Hilal and Badran 1990; Abelson et al. 1999), shipping and port activities (Abu-Hilal 1985; Badran and Foster 1998), and tourism (Riegl and Velimirov 1991; Hawkins and Roberts 1994).

Detailed ecological information on reef organisms is needed for conservation and for proper management of coral reef ecosystems. This study investigates for the first time the fish communities of shallow-water habitats along the Jordanian coast to obtain ecological information to facilitate a proper management of the Red Sea Marine Peace Park and adjacent waters of the Jordanian coast. The main objectives of the study are: (1) to investigate the community structure of fishes on coral reefs and seagrass meadows, (2) to reveal the ecological parameters which influence the community structure, (3) to detect general features of fish communities on coral reefs, (4) to describe the biodiversity of the ichthyofauna, and (5) to assign the biogeographic affinity of the shore fishes in the Gulf of Aqaba.

\section{Methods}

Study area

This study was conducted at five coral reefs (sites $1-3,5,6)$ and one seagrass meadow (site 4) along the $27 \mathrm{~km}$ Jordanian coast, Gulf of Aqaba, Red Sea (Fig. 1). Fringing reefs are discontinuously distributed over a length of $13 \mathrm{~km}$ along the coast, separated by bays that are usually covered by seagrass meadows (UNEP/IUCN 1988). Studies of a $25 \mathrm{~m}^{2}$ quadrat on the reef slope in the reserve at the Marine Science Station (Fig. 1) recorded 78 scleractinian coral species (Mergner and Schuhmacher 1981). Reef morphology and zonation is described in detail by Mergner and Schuhmacher (1974). The largest seagrass meadow along the coast is located at Al-Mamlah Bay (site 4) (UNEP/IUCN 1988). The meadows are composed of the seagrass species Halophilia ovalis, Halophilia stipulacea and Halodule universis, which is the dominant species at Al-Mamlah Bay (Wahbeh 1981).

\section{Visual census}

The fish communities in shallow-water habitats (fringing coral reef and seagrass meadow) along the Jordanian Red Sea coast were surveyed by the visual census technique using SCUBA as described by English et al. (1994). Transects of $50 \mathrm{~m}$ length and $5 \mathrm{~m}$ width $\left(250 \mathrm{~m}^{2}\right)$ were marked at the study sites (Fig. 1). At each site visual censuses were conducted along three transects at the shallow slope $(6 \mathrm{~m})$ and deep slope $(12 \mathrm{~m})$, respectively. The distance between the transects at each site was 10-20 m. The observer waited 5-10 min after laying the transect line to allow fish-

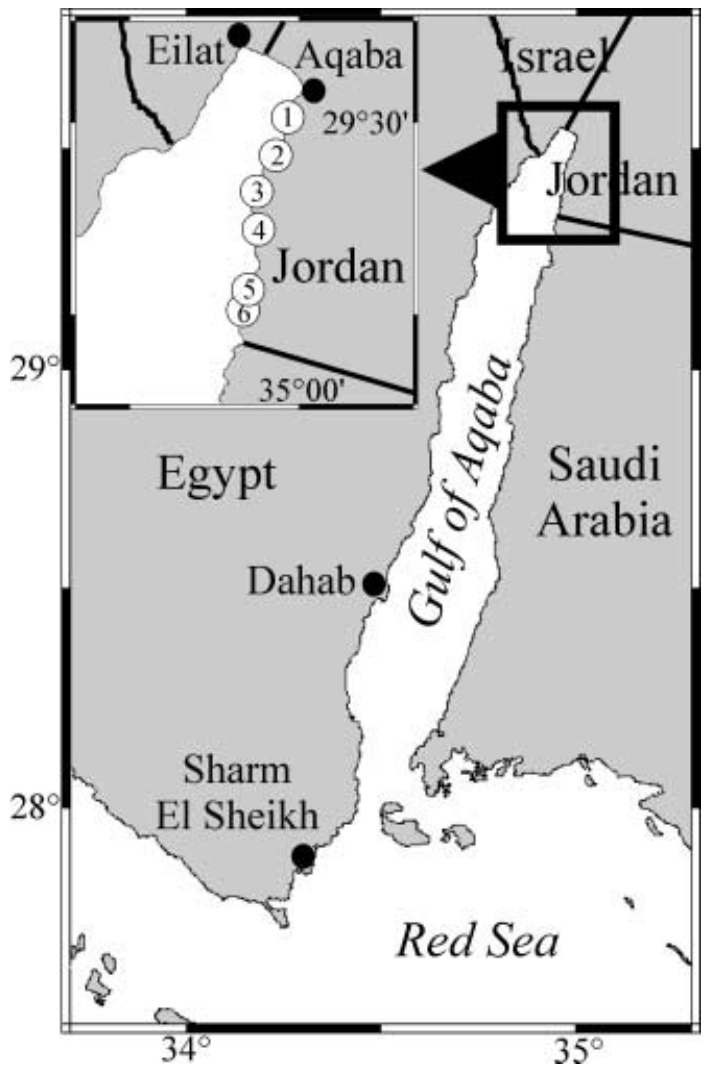

Fig. 1 Map of the Gulf of Aqaba with study sites on the Jordanian coast (inset): 1 Cement jetty $\left(29^{\circ} 28.990^{\prime} \mathrm{N} ; 34^{\circ} 59.010^{\prime} \mathrm{E}\right), 2 \mathrm{Ma}-$ rine Science Station $\left(29^{\circ} 27.250^{\prime} \mathrm{N}\right.$; $\left.34^{\circ} 58.359^{\prime} \mathrm{E}\right), 3$ Tourist Camp $\left(29^{\circ} 26.351^{\prime} \mathrm{N} ; 34^{\circ} 58.272^{\prime}\right.$ E), 4 Al-Mamlah Bay $\left(29^{\circ} 24.345^{\prime} \mathrm{N} ; 34^{\circ} 549^{\prime} \mathrm{E}\right), 5$ and 6 Jordan Fertiliser Industries and Jordan Fertiliser Industries jetty $\left(29^{\circ} 22.134^{\prime} \mathrm{N} ; 34^{\circ} 57.667^{\prime} \mathrm{E}\right)$

es to resume their normal behaviour. Subsequently the diver swam along the transect and recorded all fishes encountered $2.5 \mathrm{~m}$ on each site of the line and $5 \mathrm{~m}$ above the transect. All observed fishes of $30 \mathrm{~mm}$ total length or longer were identified by the first author (M.A. Khalaf) and recorded on a plastic slate. The duration for the count of each transect was 50-60 min. At five sites (Cement Jetty, Marine Science Station, Tourist Camp, Jordan Fertiliser Industries and Jordan Fertiliser Industries Jetty) three censuses were conducted at each depth in November 1999 and March 2000. At Al-Mamlah Bay 39 censuses were conducted at $6 \mathrm{~m}$ and 43 censuses at $12 \mathrm{~m}$ depth in 1997 and 1998 (Table 1). The survey of the benthic habitat at each visual census transect was conducted by the line-intercept method, recording percentage cover of live hard coral, live soft coral, dead coral and rock, sand, and seagrass (English et al. 1994).

Statistical analysis

Abundance of fishes was described by relative abundance (RA) and frequency of appearance (FA), calculated as follows: RA = (the pooled average abundance of species $i$ from each depth and site/the pooled average abundance of all species from each depth and site) $\times 100$ and FA $=$ (number of transects in which species $i$ was present/total number of all transects $) \times 100$. Calculation of RA with average values was necessary to prevent over-valuation of Al-Mamlah Bay.

Community indices such as fish abundance, species richness (number of species) and Shannon-Wiener diversity ( $H^{\prime}$; ln basis) were compared among sites and depths using one-way ANOVA. 
Table 1 Sampling at sites along the Jordanian Red Sea coast, Gulf of Aqaba

\begin{tabular}{lrlrl}
\hline Site & $n$ & 6 m depth & $n$ & $12 \mathrm{~m}$ depth \\
\hline Cement Jetty & 3 & November 1999 & 3 & November 1999 \\
Marine Science Station (MSS) & 3 & November 1999 & 3 & November 1999 \\
Tourist Camp & 3 & November 1999 & 3 & November 1999 \\
Al-Mamlah Bay & 39 & April 1997-August 1999 & 43 & April 1997-August 1999 \\
Jordan Fertilizer Industries (JFI) & 3 & April 2000 & 3 & April 2000 \\
Jordan Fertilizer Industries Jetty (JFI Jetty) & 3 & April 2000 & 3 & March 2000 \\
\hline
\end{tabular}

Table 2 Benthic habitat at sites along the Jordanian Red Sea coast, Gulf of Aqaba. Average percentage of cover at the study sites

\begin{tabular}{|c|c|c|c|c|c|c|}
\hline \multirow[t]{2}{*}{ Site } & \multicolumn{6}{|c|}{ Average percentage } \\
\hline & $\begin{array}{l}\text { Live stony } \\
\text { coral }\end{array}$ & $\begin{array}{l}\text { Live soft } \\
\text { coral }\end{array}$ & $\begin{array}{l}\text { Dead coral } \\
\text { and rock }\end{array}$ & Seagrass & Sand & \\
\hline Cement Jetty & 17 & 7 & 26 & 0 & 50 & Coral reef \\
\hline Marine Science Station & 22 & 3 & 30 & 0 & 45 & Coral reef \\
\hline Tourist Camp & 23 & 6 & 47 & 0 & 24 & Coral reef \\
\hline Al-Mamlah Bay & 3 & 3 & 8 & 59 & 27 & $\begin{array}{l}\text { Seagrass } \\
\text { meadow }\end{array}$ \\
\hline Jordan Fertilizer Industries & 22 & 4 & 21 & 0 & 53 & Coral reef \\
\hline Jordan Fertilizer Industries Jetty & 13 & 5 & 25 & 0 & 57 & Coral reef \\
\hline
\end{tabular}

Homogeneity of variances was tested with the $F$-test and if necessary, data were $\log (1+x)$ transformed to obtain homogeneity of variances. If transformation of the data did not lead to homogeneity of variances, no statistical test was conducted. $F$-tests were performed with a spreadsheet analysis program and one-way ANOVA was carried out using STATISTICA 5.1 (StatSoft 1997).

Regression analysis (power and linear regression) was performed with a spreadsheet analysis program and the significance level of the correlation was obtained from statistical tables after calculating the empirical $F$-value with the following formula: $\left.F_{\text {emp }}=\left(r^{2}-J\right) /\left(\left(1-r^{2}\right) / K-J-1\right)\right)$; where $r^{2}=$ coefficient of determination; $J=$ number of regressors; $K=$ sample size (Backhaus et al. 1994).

Multivariate analysis of the data such as cluster analysis, MDS (multi-dimensional scaling), RELATE, BIO-ENV, as well as the ANOSIM (analysis of similarities) significance test were performed using PRIMER-5 software (Primer-E 2000). Hierarchical clustering and MDS was based on Bray-Curtis similarities of abundance data. Highly abundant species, in contrast to species with very low abundance, can disturb the analysis. Therefore, if necessary, data were transformed and standardised as indicated in the figures. MDS is a 3-dimensional ordination of samples brought down to a 2-dimensional plot. The quality of the MDS plot is indicated by the stress value. Values $<0.2$ give a potentially useful 2-dimensional picture, stress $<0.1$ corresponds to a good ordination and stress $<0.05$ gives an excellent representation.

The ANOSIM significance test compares similarities of species compositions between the samples and can give evidence for differences. A one-way layout of ANOSIM was performed with the original data; no transformation or standardisation was conducted. Two terms are important in an ANOSIM significance test: $P$ (significance level) and Global $R$. Global $R$ indicates the degree of similarity between the tested groups with values between -1 and 1 . If all replicates within sites are more similar to each other than any replicate from different sites, the value of $R$ is 1 . Values close to zero indicate that the similarity between sites is very high, showing a low difference between them (Clarke and Warwick 1994).

A BIO-ENV analysis was performed with PRIMER-5; this correlates environmental variables to the multivariate analysis of the fish community based on a weighted Spearman rank correla- tion. RELATE compares the multivariate analysis of the fish community to the benthic habitat and reveals the degree of correlation between the two data sets (Clarke and Warwick 1994).

A biogeographic comparison was performed on the basis of species lists from 21 sites in the Red Sea (Vine and Vine 1980; Krupp et al. 1993; Schraut 1995; Rilov and Benayahu 2000; W. Gladstone, unpublished report; M.A. Khalaf and F. Krupp, unpublished data; U. Zajonz et al., unpublished report), the Arabian Gulf (Coles and Tarr 1990; Krupp et al. 1994; Krupp and Almarri 1996; Carpenter et al. 1997), the Gulf of Aden (Kemp 1998, 2000), Oman (Randall 1995) and the Indian Ocean (Smith and Heemstra 1991; Randall and Anderson 1993; Letourneur 1996; Pittman 1996; Öhman et al. 1997; Winterbottom and Anderson 1997; Anderson et al. 1998; Kunzmann et al. 1999). Presence/absence data for 712 species from the following families were considered for the biogeographic comparison: Acanthuridae, Balistidae, Caesionidae, Chaetodontidae, Haemulidae, Labridae, Lethrinidae, Lutjanidae, Nemipteridae, Pomacanthidae, Pomacentridae, Scaridae, Serranidae and Siganidae. All species names were checked for synonyms with FishBase 99 (FishBase 1999) to prevent double counts of species. Multivariate statistics for the biogeographic analysis was based on Bray-Curtis similarity and Euclidean distance.

\section{Results}

\section{Benthic habitat}

Along the Jordanian Red Sea coast the highest live coral cover was $35 \%$ and the average $19 \%$. Five of the study sites were coral reefs, whereas Al-Mamlah Bay was dominated by seagrasses ( $59 \%$ cover). At all coral reefs dead coral and rock as well as sand made up most of the cover (Table 2). 


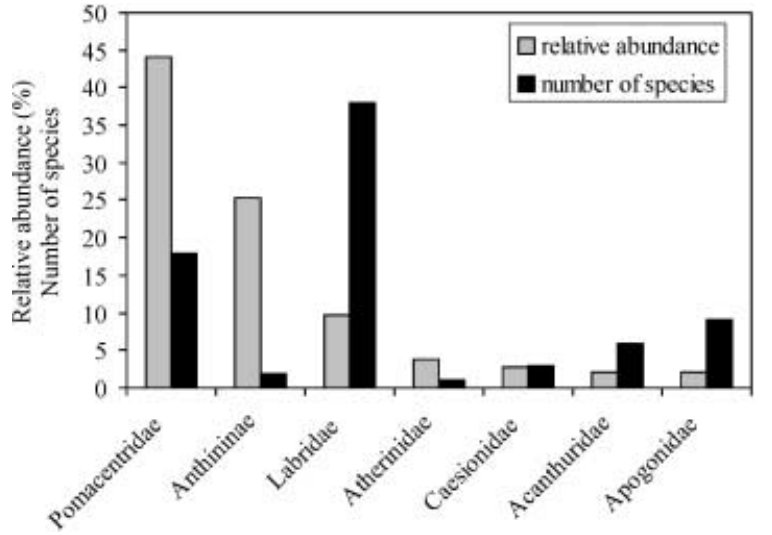

Fig. 2 Dominant families of the ichthyofauna on visual census transects $\left(250 \mathrm{~m}^{2}\right)$ at the Jordanian Red Sea coast, Gulf of Aqaba
Fish assemblages and community indices

In this study a total of 212,349 fishes were counted, representing 198 shallow-water species belonging to 121 genera and 43 families. Most individuals belonged to the families Pomacentridae (44.1\%, 18 species), Anthininae (25.3\%, 2 species, subfamily of Serranidae), Labridae (9.7\%, 38 species), Atherinidae (3.9\%, 1 species), Caesionidae $(2.7 \%, 3$ species $)$, Acanthuridae (2.2\%, 6 species) and Apogonidae (2.1\%, 9 species) (Fig. 2). In terms of species richness per family the ichthyofauna showed the following ranking: Labridae (19.2\%), Pomacentridae $(9.1 \%)$, Gobiidae $(5.1 \%)$, Scaridae $(5.1 \%)$, Blenniidae (4.5\%), Apogonidae (4.0\%), Chaetodontidae (4.0\%), Scorpaenidae $(4.5 \%)$ and Serranidae $(3.5 \%)$ (Table 3). The most abundant species were Pseudanthias squamipinnis (24.1\%), Pomacentrus trichourus (16.1\%), Paracheilinus octotaenia (6.4\%), Neopomacentrus miry-

1994 (VC+F+R), ${ }^{10}$ Pittman 1996 (VC), ${ }^{11}$ Harmelin-Vivien 1989 (?), 12Letourneur 1996 (VC), 13Letourneur et al. 1997 (VC+R), ${ }^{14}$ Williams and Hatcher 1983 (E), ${ }^{15}$ Gladfelter et al. 1980 (VC), 16Pattengill et al. 1997 (VC). $V C$ visual census, $F$ fishing, $R$ rotenone, $E$ explosive charges
Table 3 Percentage of species of the most abundant fish families at the Jordanian Red Sea coast, Gulf of Aqaba in comparison to other fish assemblages on coral reefs. ${ }^{1}$ This study (VC), ${ }^{2}$ Rilov and Benayahu 2000 (VC), ${ }^{3}$ Zajonz et al. unpubl. report (VC), ${ }^{4}$ Schraut 1995 (VC), ${ }^{5}$ Krupp et al. 1993 (VC+F), ${ }^{6}$ Kemp 1998 (VC), ${ }^{7}$ Kemp 2000 (VC), ${ }^{8}$ Coles and Tarr 1990 (VC), ${ }^{9}$ Krupp et al.

\begin{tabular}{|c|c|c|c|c|c|c|c|c|c|c|}
\hline Location & Region & Labridae & $\begin{array}{l}\text { Poma- } \\
\text { centridae }\end{array}$ & Gobiidae & Scaridae & $\begin{array}{l}\text { Blenni- } \\
\text { idae }\end{array}$ & $\begin{array}{l}\text { Apogon- } \\
\text { idae }\end{array}$ & $\begin{array}{l}\text { Chaeto- } \\
\text { dontidae }\end{array}$ & $\begin{array}{l}\text { Scorpaen- } \\
\text { idae }\end{array}$ & $\begin{array}{l}\text { Serran- } \\
\text { idae }\end{array}$ \\
\hline Aqaba $^{1}$ & Red Sea & 19.2 & 9.1 & 5.1 & 5.1 & 4.5 & 4.0 & 4.0 & 4.0 & 3.5 \\
\hline Eilat $^{2}$ & Red Sea & 20.4 & 12.7 & 2.1 & 5.6 & 7.7 & 2.1 & 4.9 & 2.1 & 6.3 \\
\hline Dahab $^{3}$ & Red Sea & 13.7 & 11.9 & 1.2 & 3.6 & 3.0 & 4.2 & 5.4 & 2.4 & 7.7 \\
\hline Sharm El Sheikh 4 & Red Sea & 14.8 & 10.2 & 2.3 & 4.0 & 5.1 & 2.3 & 5.1 & 2.3 & 6.3 \\
\hline Sanganeb $^{5}$ & Red Sea & 12.4 & 9.6 & 7.2 & 3.6 & 3.6 & 4.8 & 4.8 & 2.0 & 5.2 \\
\hline Socrota $^{6}$ & $\begin{array}{l}\text { Gulf of } \\
\text { Aden }\end{array}$ & 11.1 & 7.9 & 1.4 & 1.9 & 0.9 & 2.8 & 6.0 & 1.4 & 6.9 \\
\hline Yemen $^{7}$ & $\begin{array}{l}\text { Gulf of } \\
\text { Aden }\end{array}$ & 12.5 & 7.6 & 4.5 & 3.0 & 3.0 & 2.7 & 6.8 & 1.5 & 4.9 \\
\hline Jubail $^{8}$ & $\begin{array}{l}\text { Arabian } \\
\text { Gulf }\end{array}$ & 7.9 & 9.9 & 4.0 & 5.9 & 5.0 & 5.0 & 3.0 & - & 5.0 \\
\hline Jubail $^{9}$ & $\begin{array}{l}\text { Arabian } \\
\text { Gulf }\end{array}$ & 4.3 & 4.8 & 9.1 & 2.1 & 2.2 & 3.2 & 1.6 & 2.7 & 4.3 \\
\hline Seychelles ${ }^{10}$ & $\begin{array}{l}\text { Western } \\
\text { Indian } \\
\text { Ocean }\end{array}$ & 11.8 & 7.5 & 0.4 & 5.9 & 0.8 & 1.3 & 6.7 & 2.5 & 5.4 \\
\hline Tulear $^{11}$ & $\begin{array}{l}\text { Western } \\
\text { Indian } \\
\text { Ocean }\end{array}$ & 11.2 & 7.4 & 9.1 & 2.5 & 4.5 & 4.3 & 3.8 & 4.0 & 4.3 \\
\hline Réunion ${ }^{12}$ & $\begin{array}{l}\text { Western } \\
\text { Indian } \\
\text { Ocean }\end{array}$ & 14.3 & 11.5 & 1.8 & 4.1 & 3.2 & 1.4 & 7.4 & 3.7 & 3.7 \\
\hline Réunion ${ }^{13}$ & $\begin{array}{l}\text { Western } \\
\text { Indian } \\
\text { Ocean }\end{array}$ & 13.5 & 11.2 & 1.2 & 3.2 & 2.4 & 1.7 & 7.0 & - & 3.2 \\
\hline Gt Barrier Reef ${ }^{14}$ & $\begin{array}{l}\text { Western } \\
\text { Pacific }\end{array}$ & 14.2 & 17.6 & 6.5 & 4.3 & - & 5.3 & 8.7 & - & 6.8 \\
\hline New Caledonia ${ }^{13}$ & $\begin{array}{l}\text { Western } \\
\text { Pacific }\end{array}$ & 15.0 & 16.5 & 1.5 & 5.8 & 0.5 & 3.0 & 9.5 & - & 6.1 \\
\hline Moorea $^{11}$ & $\begin{array}{l}\text { Central } \\
\text { Pacific }\end{array}$ & 13.6 & 8.9 & 3.9 & 4.3 & 2.1 & 5.0 & 6.8 & 2.1 & 3.6 \\
\hline Moorea $^{13}$ & $\begin{array}{l}\text { Central } \\
\text { Pacific }\end{array}$ & 15.8 & 9.5 & 3.2 & 1.1 & - & 5.7 & 10.1 & - & 1.1 \\
\hline Enewetak $^{15}$ & $\begin{array}{l}\text { Central } \\
\text { Pacific }\end{array}$ & 22.5 & 12.4 & 0.6 & 5.6 & 2.2 & 2.8 & 11.2 & 1.1 & 7.3 \\
\hline St. Croix ${ }^{15}$ & Caribbean & 6.0 & 9.5 & 2.6 & 7.8 & 2.6 & 5.2 & 4.3 & 1.7 & 12.1 \\
\hline Gulf of Mexico ${ }^{16}$ & Caribbean & 5.9 & 7.8 & 3.9 & 4.6 & - & 2.6 & 3.3 & 1.3 & 11.1 \\
\hline
\end{tabular}




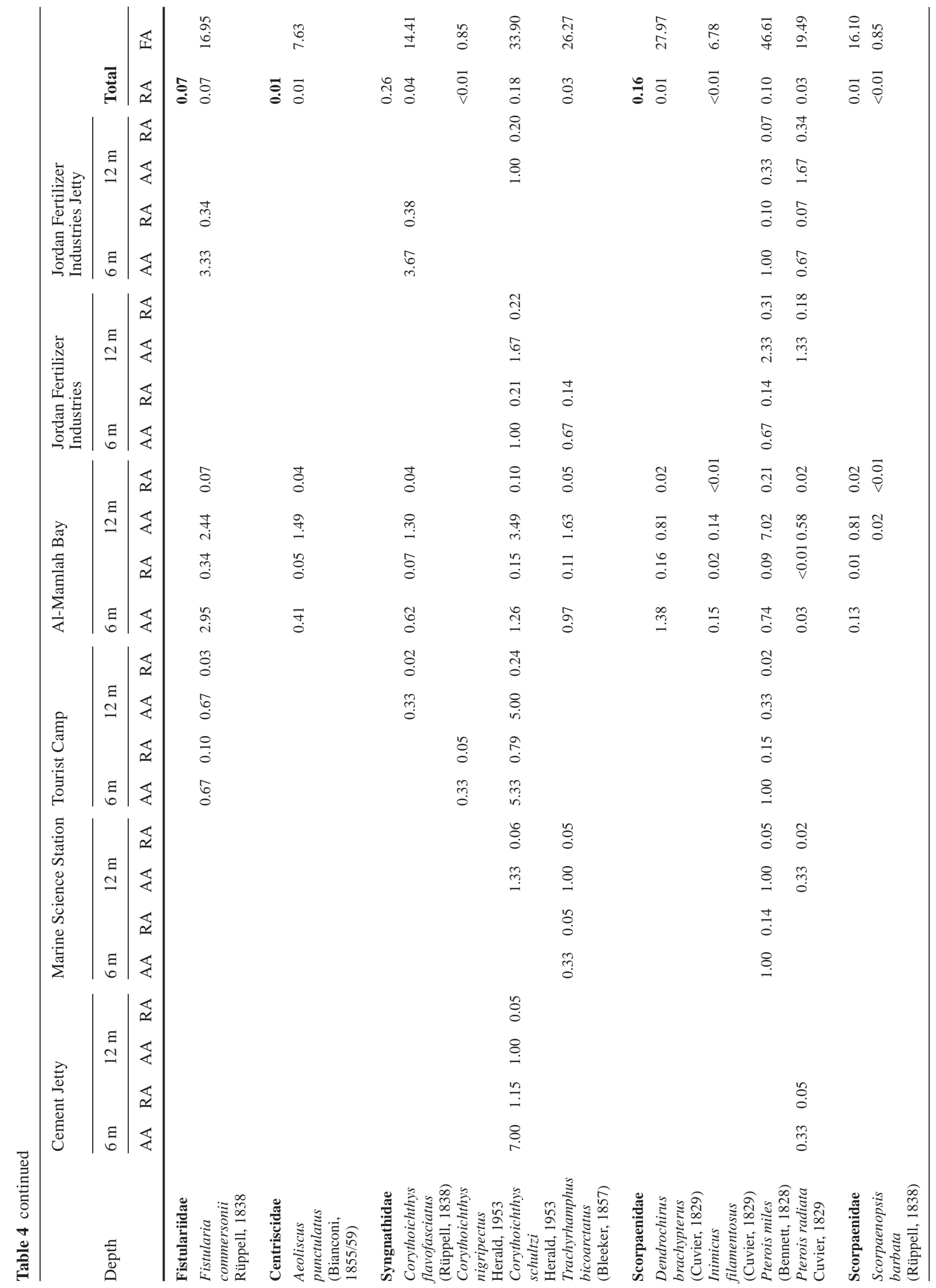




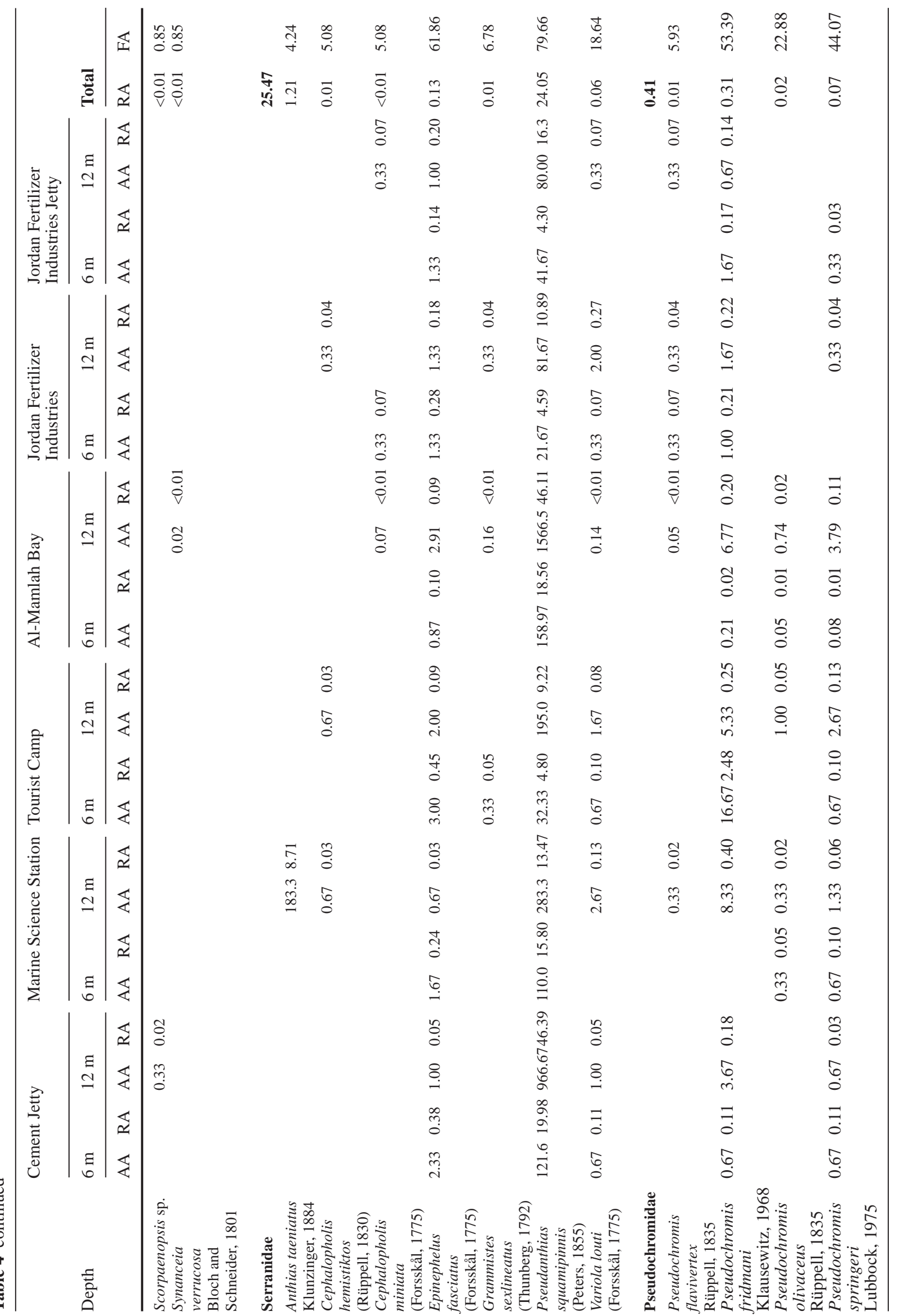




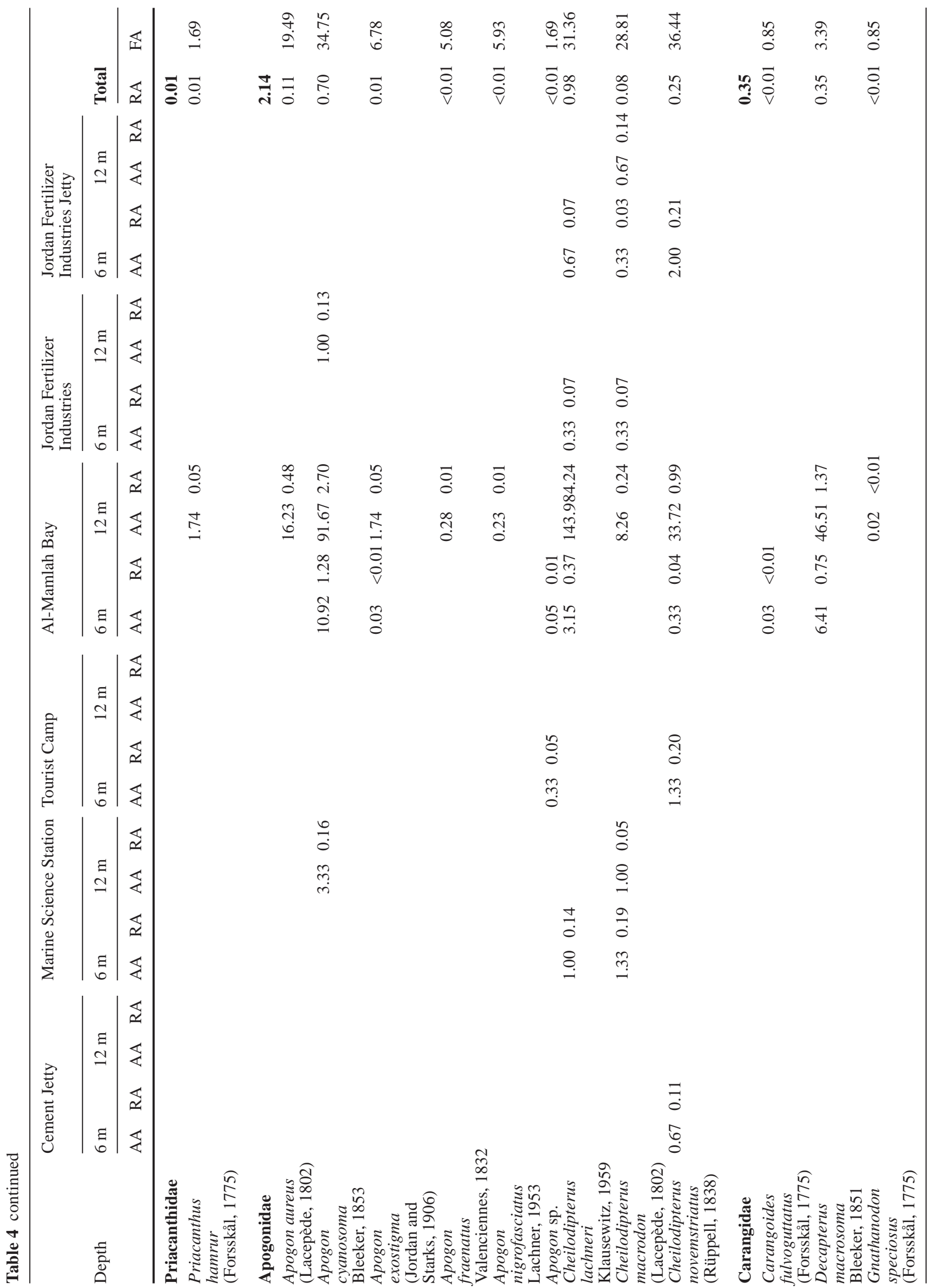




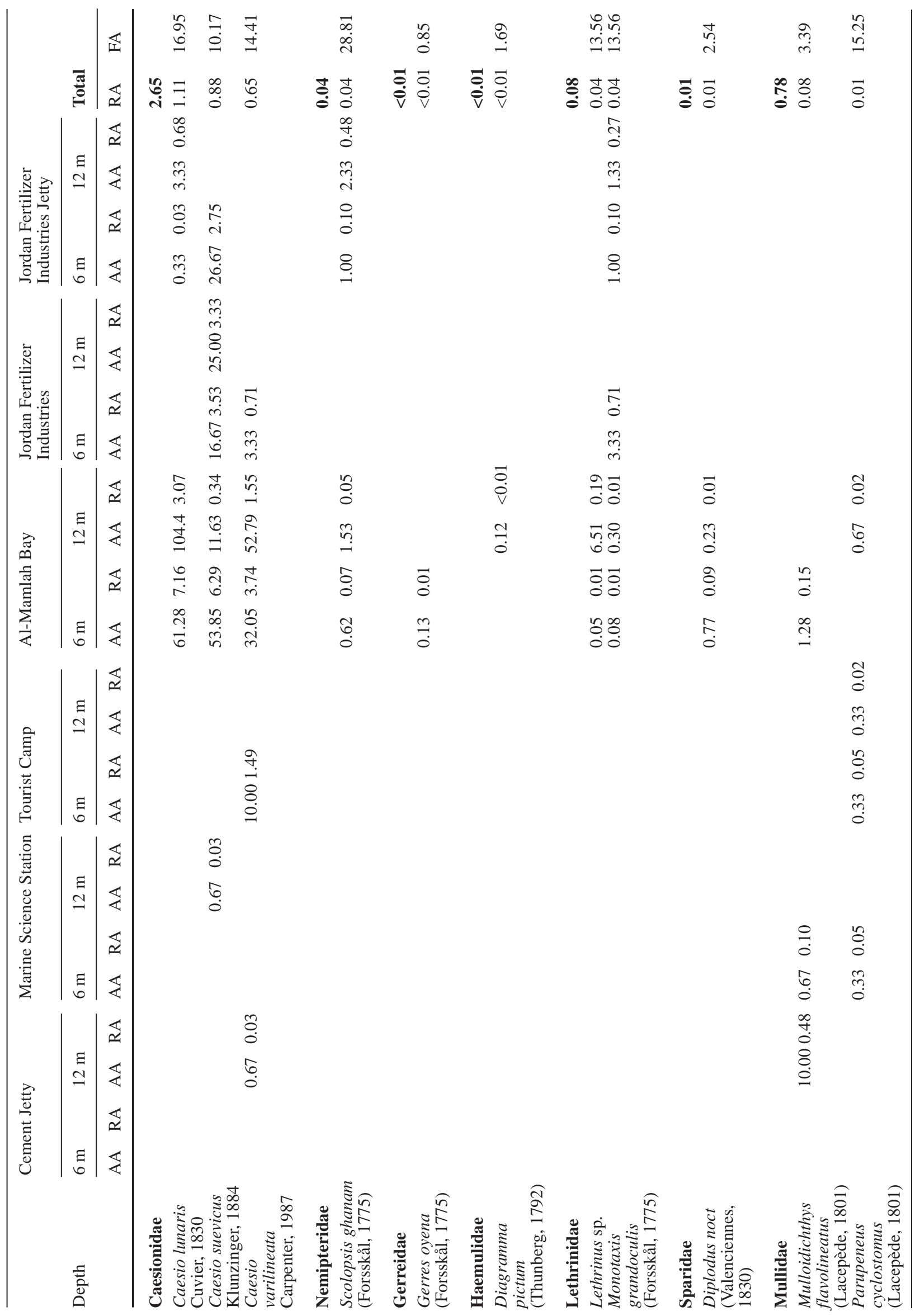




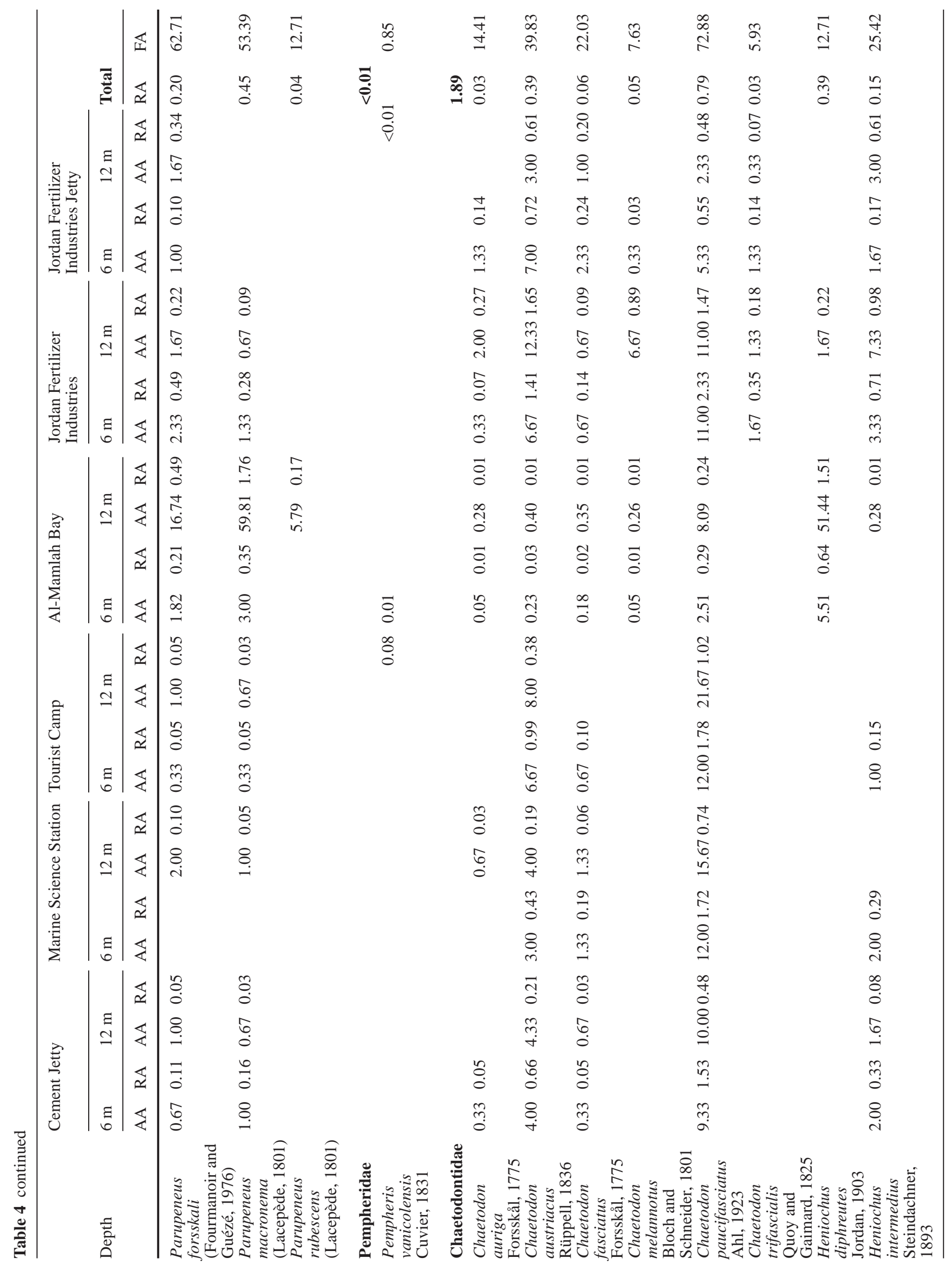




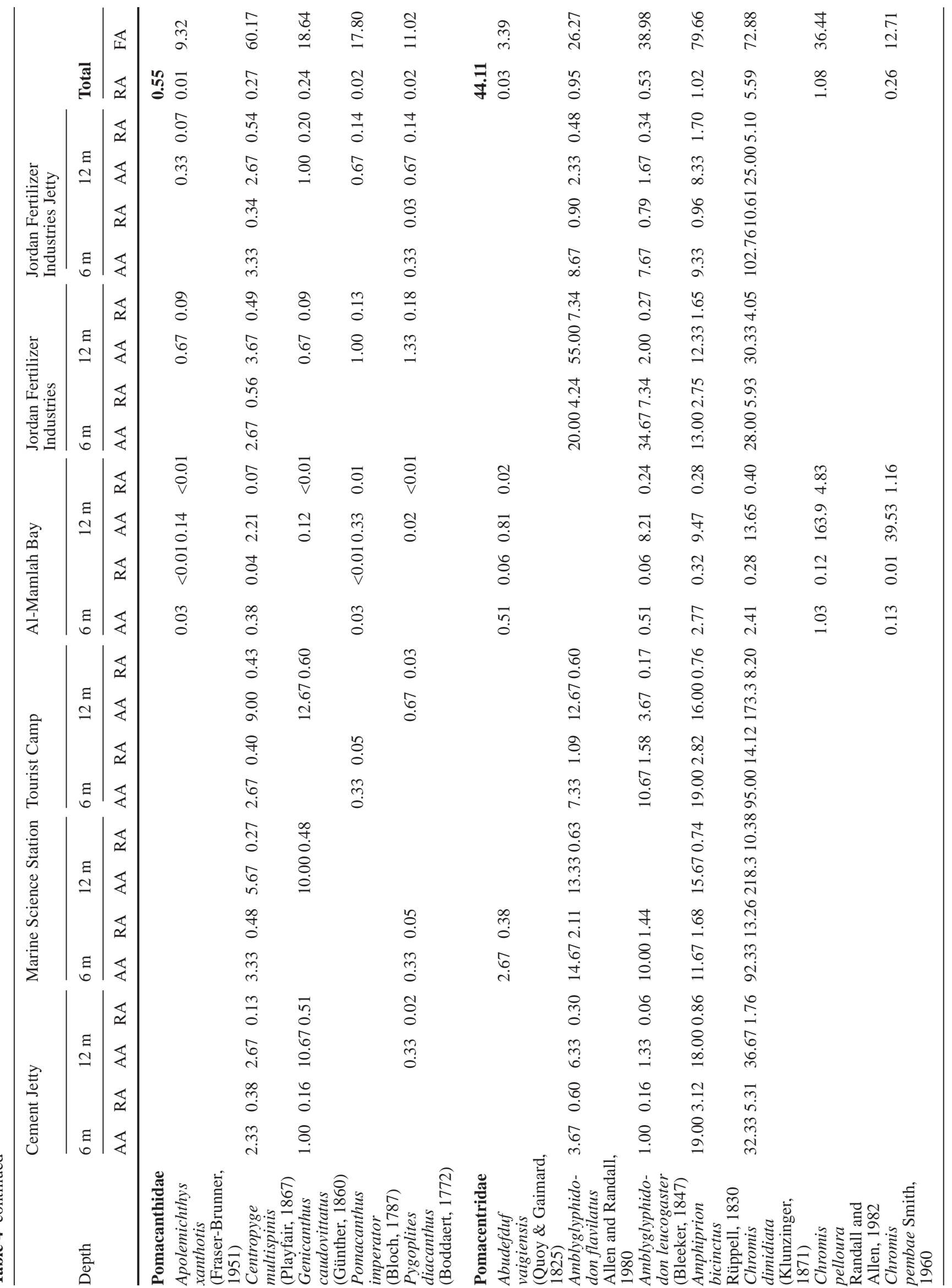




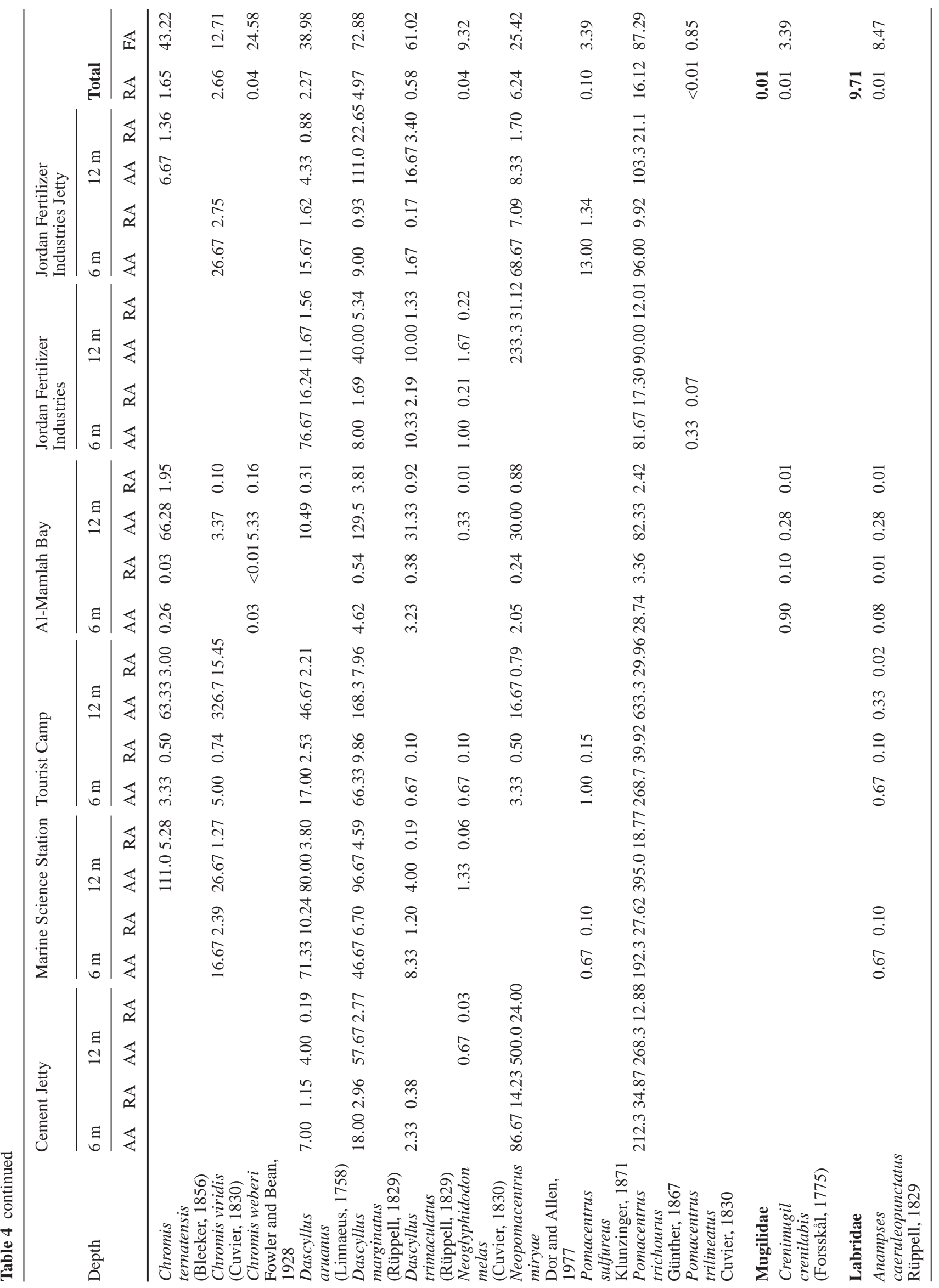




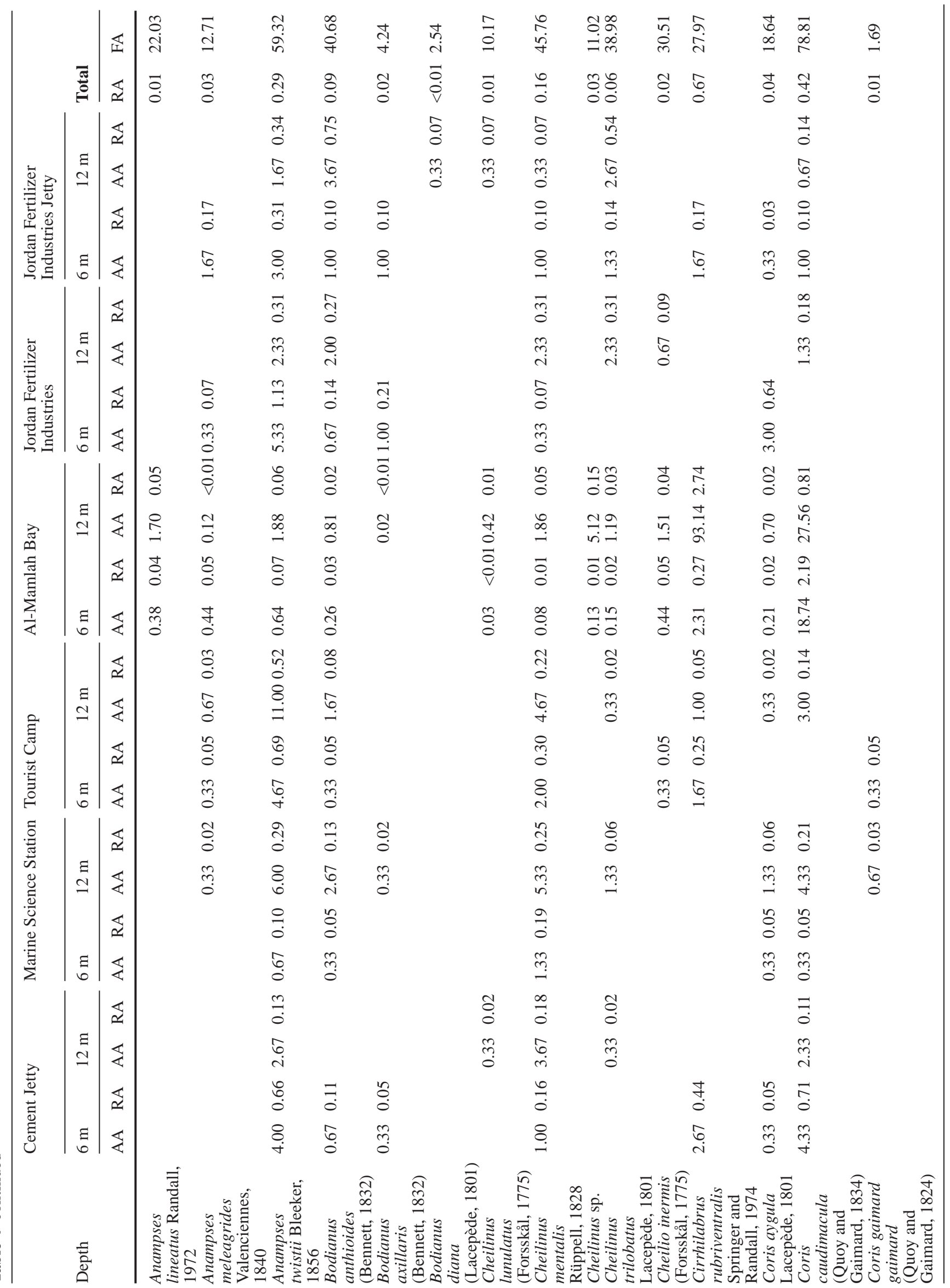




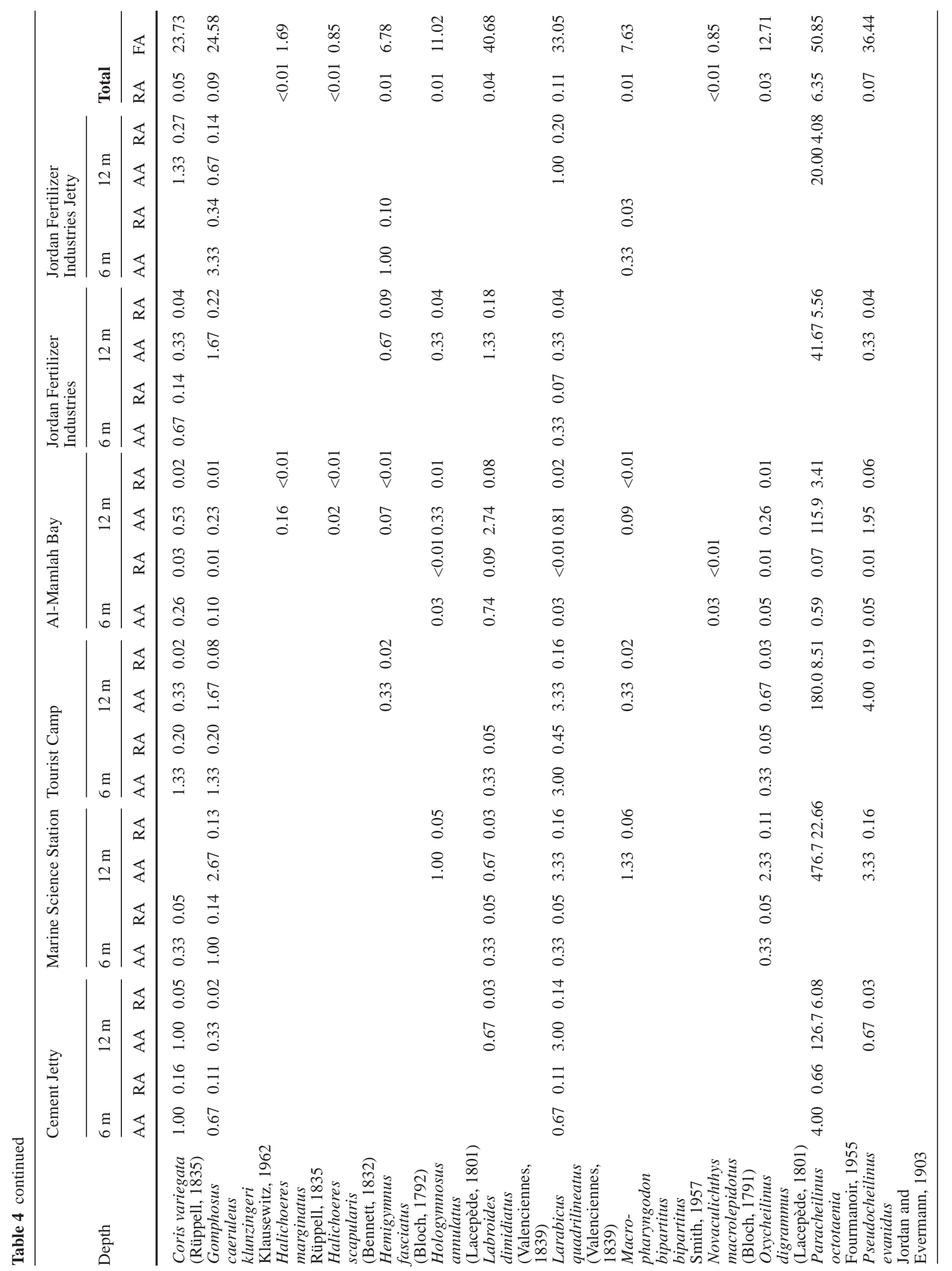




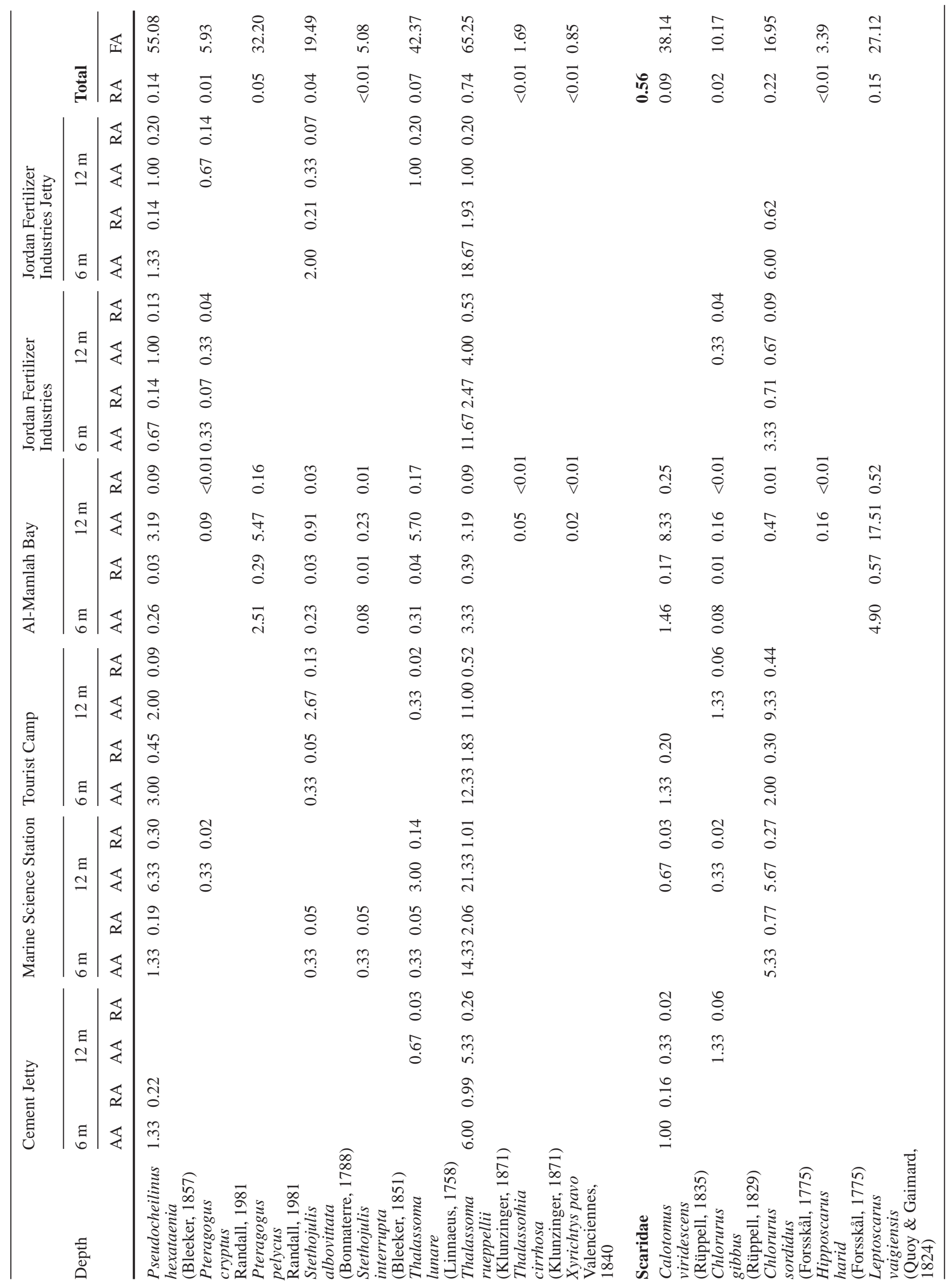




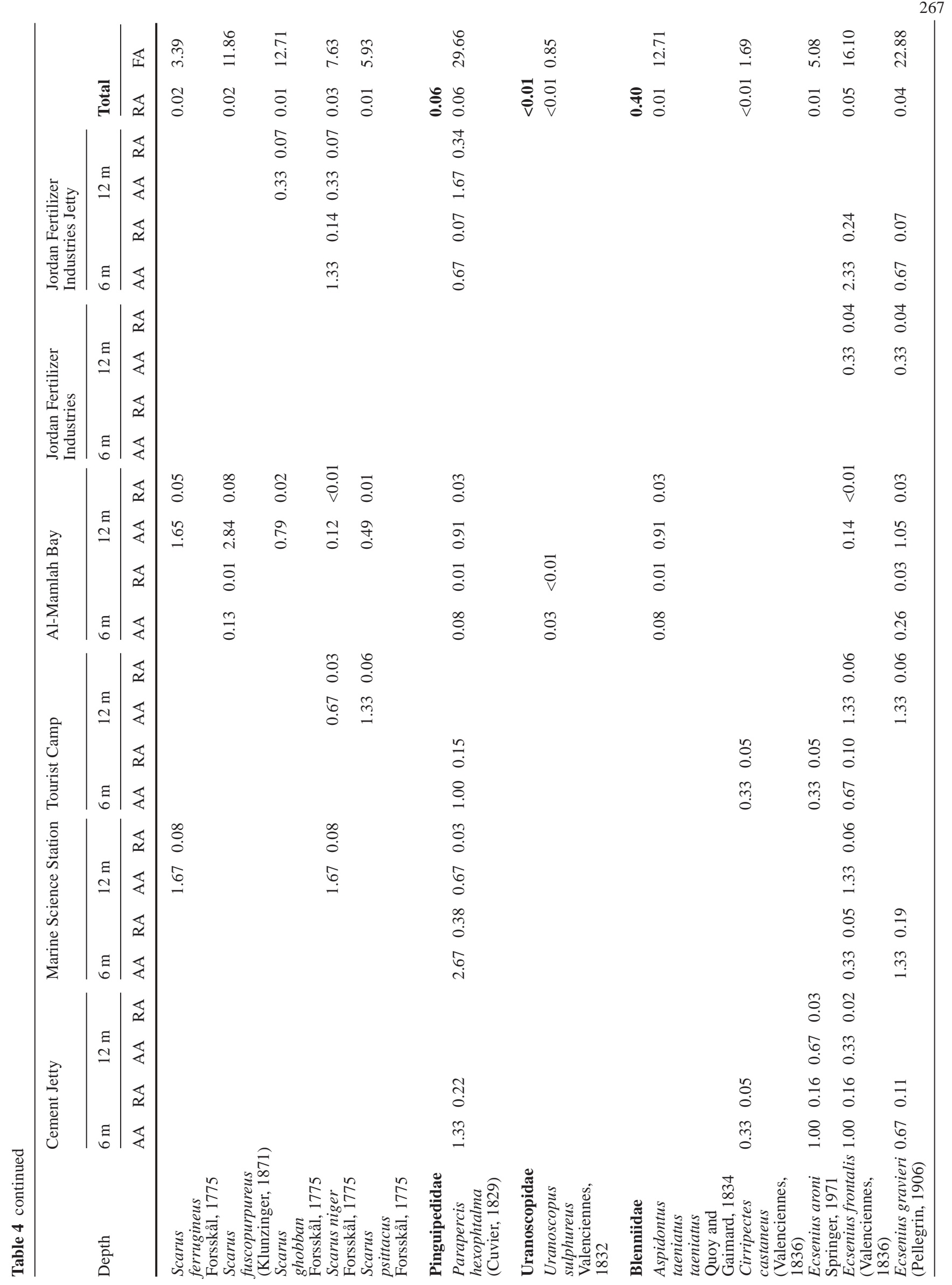




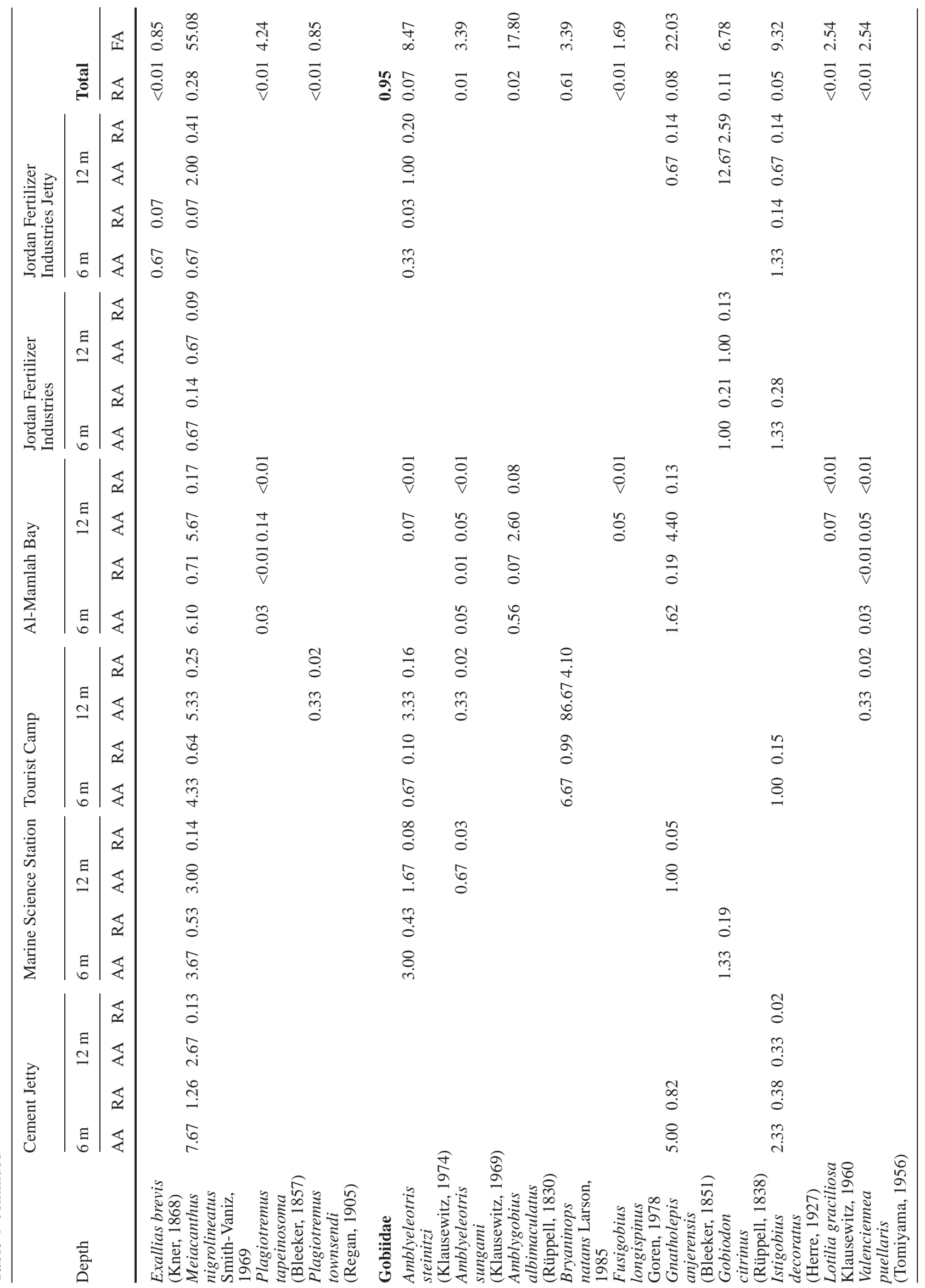




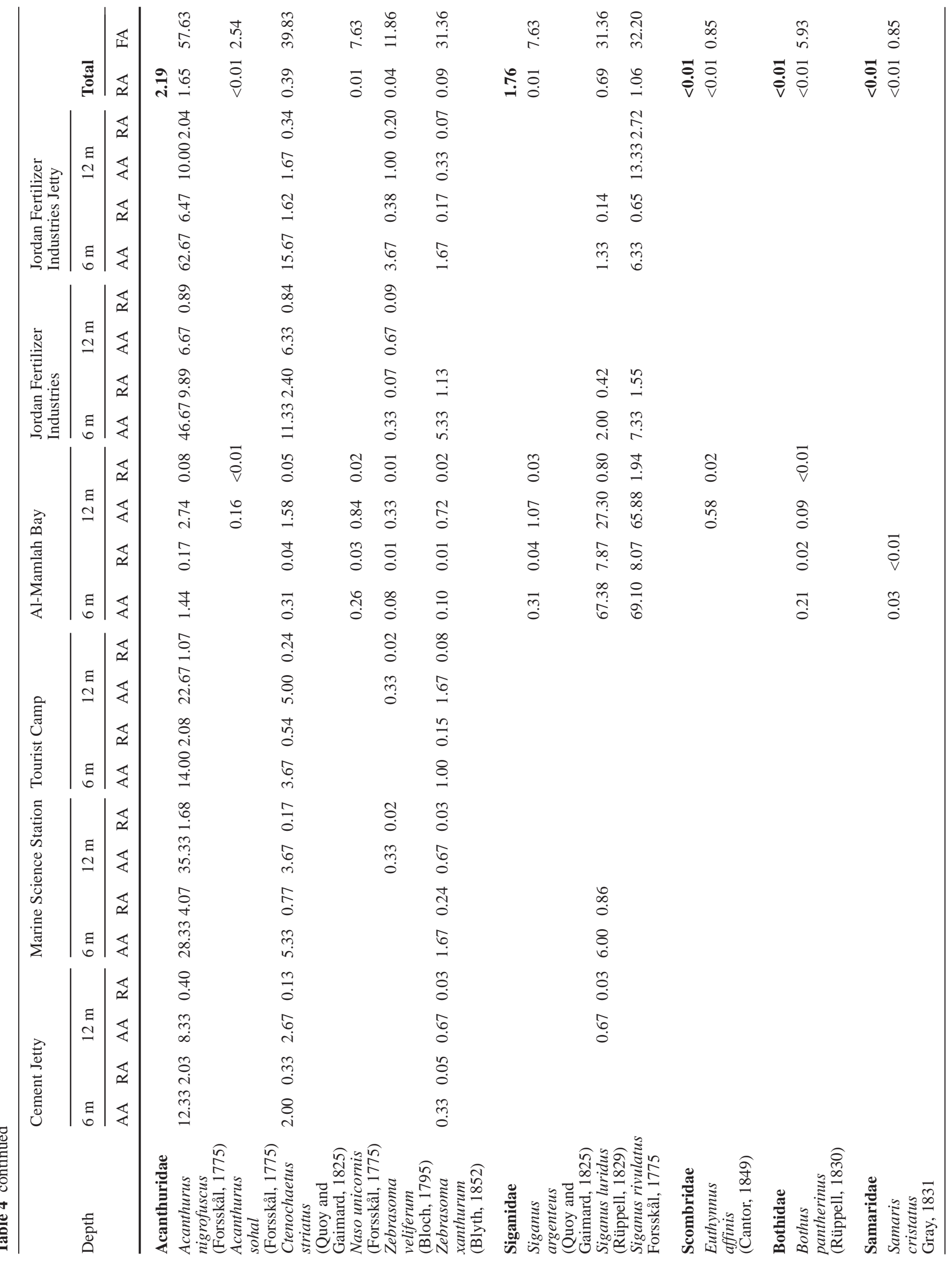




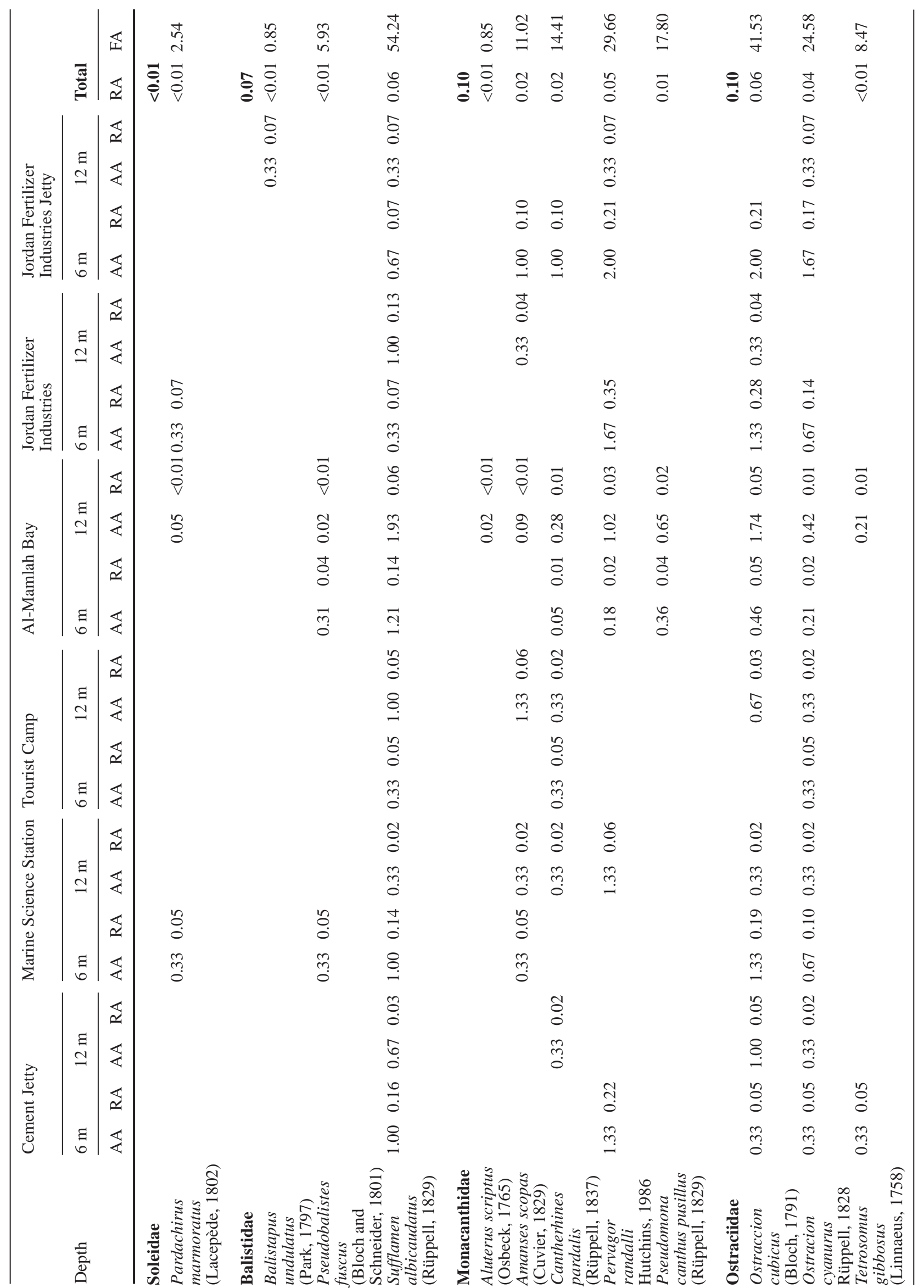




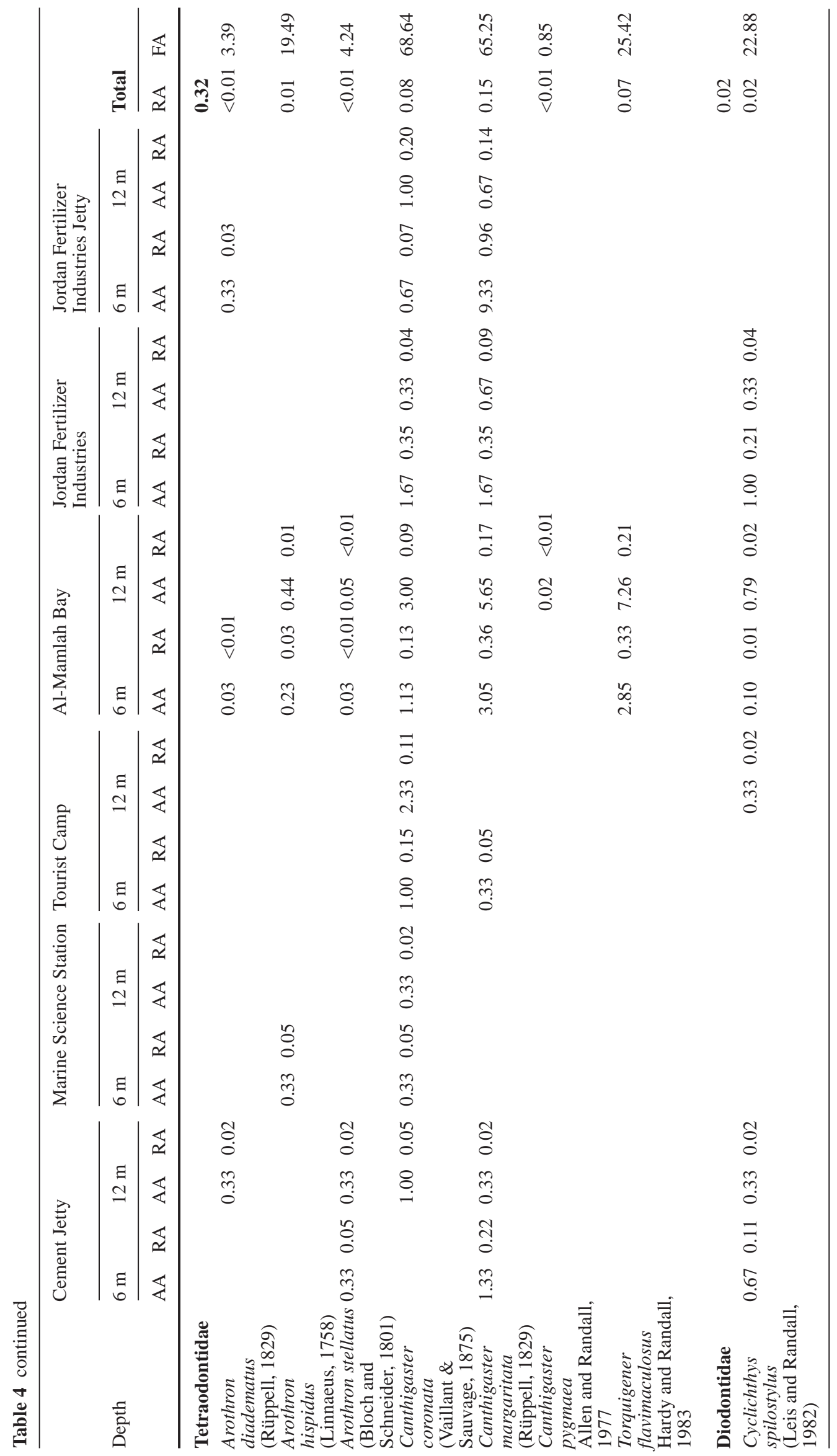


I

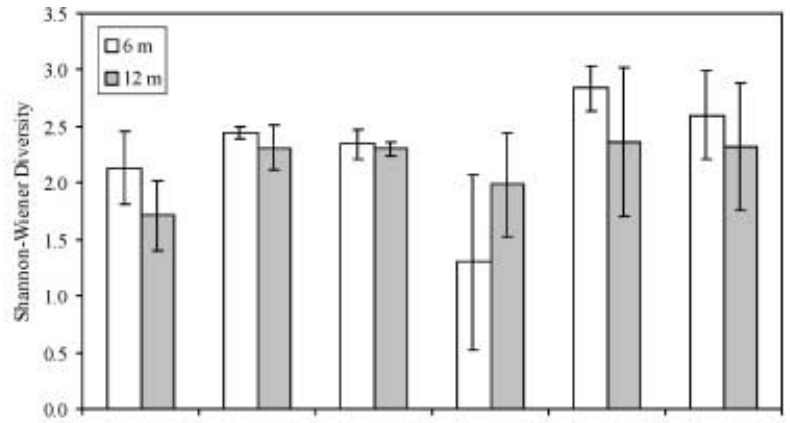

II

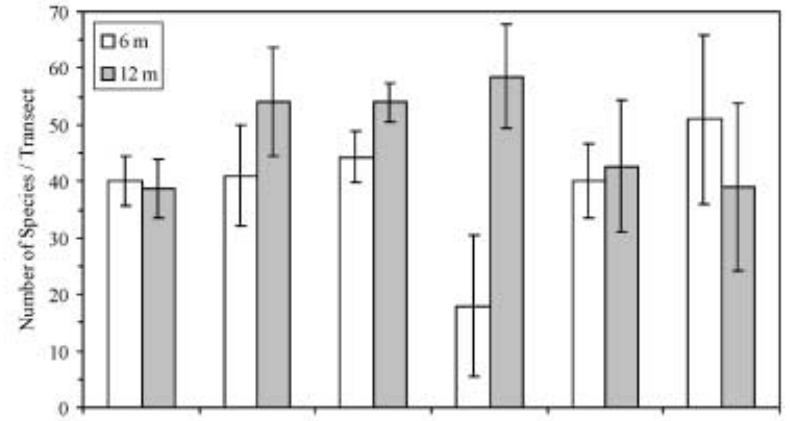

III

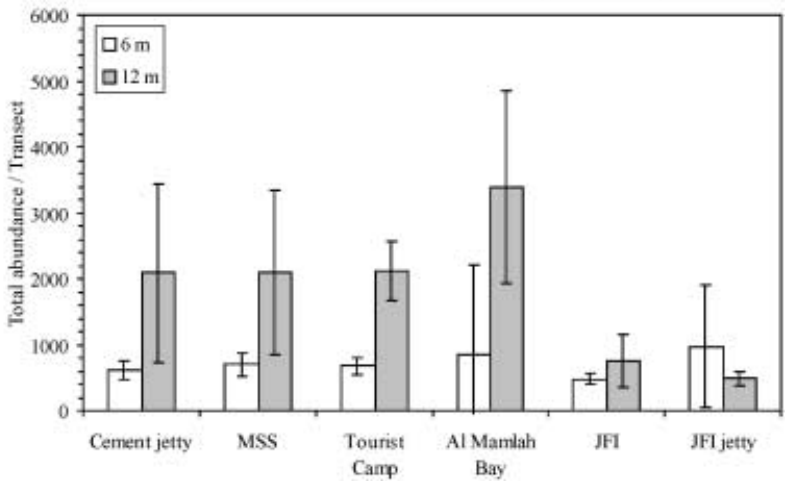

Fig. 3 I Diversity (Shannon-Wiener Index; ln basis), II species richness, and III abundance for $6 \mathrm{~m}$ and $12 \mathrm{~m}$ depths (average \pm SD) of fish assemblages at sites along the Jordanian Red Sea coast, Gulf of Aqaba

ae (6.2\%), Chromis dimidiata (5.6\%) Dascyllus marginatus (5.0\%) and Atherinomorus lacunosus (3.9\%). These seven species accounted for two-thirds of all individuals. In terms of frequency of appearance, the most common species were Pomacentrus trichourus (87.3\%), Amphiprion bicinctus (79.7\%), Pseudanthias squamipinnis $(79.7 \%)$ and Coris caudimacula $(78.8 \%)$, as well as Chaetodon paucifasciatus, Chromis dimidiata and Dascyllus marginatus (all 72.9\%) (Table 4).

Average Shannon-Wiener diversity (ln basis) ranged from 1.3 at Al-Mamlah Bay at $6 \mathrm{~m}$ depth to 2.8 at Jordan Fertiliser Industries at $12 \mathrm{~m}$ depth (Fig. 3), but no significant difference was detected (Table 5).

Average species richness ranged from 17.9 species at Al-Mamlah Bay at $6 \mathrm{~m}$ depth to 58.5 species at AlMamlah Bay at $12 \mathrm{~m}$ depth. The seagrass-dominated site, Al-Mamlah Bay, showed more species at $12 \mathrm{~m}$ than at $6 \mathrm{~m}$ depth. At $6 \mathrm{~m}$ depth species richness was higher on coral reefs than on the seagrass meadow. The picture for $12 \mathrm{~m}$ depth was the reverse, with a higher species richness at the seagrass-dominated site. All differences were evidenced with a significance level of $p<0.001$. No significant difference in species richness was detected between other sites (Table 5).

Average abundance ranged from 472 fishes per transect at Jordan Fertiliser Industries at $6 \mathrm{~m}$ depth to 3,397 fishes per transect at Al-Mamlah Bay at $12 \mathrm{~m}$ depth (Fig. 3). Higher fish abundance was observed at $12 \mathrm{~m}$ than at $6 \mathrm{~m}$ depth covering all sites $(p<0.001)$, at the seagrass-dominated site Al-Mamlah Bay $(p<0.001)$ as well as on coral reefs $(p=0.015)$. There were more fishes at $12 \mathrm{~m}$ depth at Al-Mamlah Bay compared with $12 \mathrm{~m}$ depth at the coral-dominated sites $(p<0.001)$. Due to inhomogeneous variances, no significant differences in abundance were detected at $6 \mathrm{~m}$ depth between coral reef and seagrass meadow (Table 5).

Multivariate analysis of the shore fish communities along the Jordanian Red Sea coast

Cluster analysis and MDS plot based on percentage of benthic cover revealed two main groups (Fig. 4): (A) the seagrass-dominated Al-Mamlah Bay and (B) the coral reefs with two subgroups (B.1) $6 \mathrm{~m}$ and (B.2) $12 \mathrm{~m}$ depth. Two samples ( $3 a$ and $6 b)$ did not match the clusters in the dendrogram, but $6 \mathrm{~b}$ did fit into the groups of the MDS plot. Coral reef sites at $6 \mathrm{~m}$ and $12 \mathrm{~m}$ depth were grouped together with a 1.5 times higher similarity than coral reefs to the seagrass meadow. This grouping was correlated with cluster analysis as well as MDS plot based on average fish species abundance (Fig. 4). The mismatch of sample 1a in the dendrogram and MDS plot did not disturb the general division into three groups. The RELATE test for similarities between the multivariate pattern revealed a significant correlation (Global $\rho=$ $0.638, p=0.006$ ).

An ANOSIM significance test confirmed the difference in the benthic habitat between $6 \mathrm{~m}$ and $12 \mathrm{~m}$ depths of coral reefs $(p=0.021)$ as well as between reefs and the seagrass meadow $(p<0.001)$ (Table 6). There were no significant differences between $6 \mathrm{~m}$ and $12 \mathrm{~m}$ depth regarding all sites (coral and seagrass) and the seagrassdominated site. All identified groups of the fish assemblages were evidenced by an ANOSIM significance test with $p<0.001$ (Table 6).

Species analysis by dendrogram and MDS plot revealed four main groups (Fig. 5): (A) fishes of coral reefs, with the subgroups (A.1) Apogonidae, (A.2) higher relative abundance at the shallow reef slope $(6 \mathrm{~m})$ and (A.3) higher relative abundance at the deep reef slope (12 m); (B) fishes of seagrass meadows and sand flats; (C) Siganidae; and (D) Caesionidae. Five species were not assigned to any of the groups identified above. In addition, four species showed a mismatch in the correlation to the main groups. These minor mismatches are due to uneven distribution of these species and did not disturb the overall picture. Species analysis by dendrogram and 
Fig. 4 Dendrogram (I) and MDS plot (II) of relationships between benthic habitats (BrayCurtis similarity, group average; stress $=0$ ), and dendrogram (III) and MDS plot (IV) of relationships between fish assemblages (Bray-Curtis similarity, $\log (1+x)$ transformation of data, standardisation, group average, stress $=0.05$ ) at sites along the Jordanian Red Sea coast, Gulf of Aqaba. RELATE test for similarities between the multivariate pattern: Global $\rho=0.638, p=0.006$. For site labels see Fig. 1 ( $a 6 \mathrm{~m}$ depth, $b$ $12 \mathrm{~m}$ depth). A seagrass-dominated site, $B$ coral-dominated sites (B.16 m depth, B.2 $12 \mathrm{~m}$ depth). ${ }^{+}$indicates mismatch
I

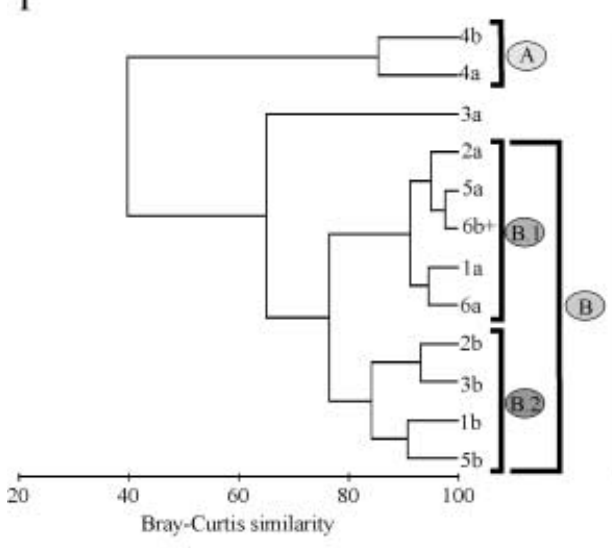

II

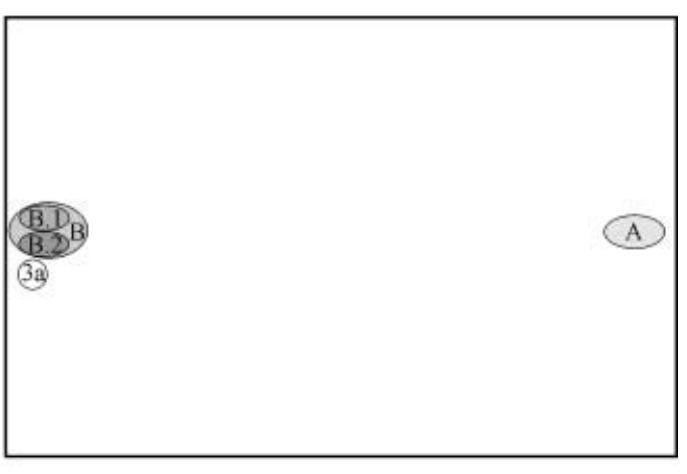

III

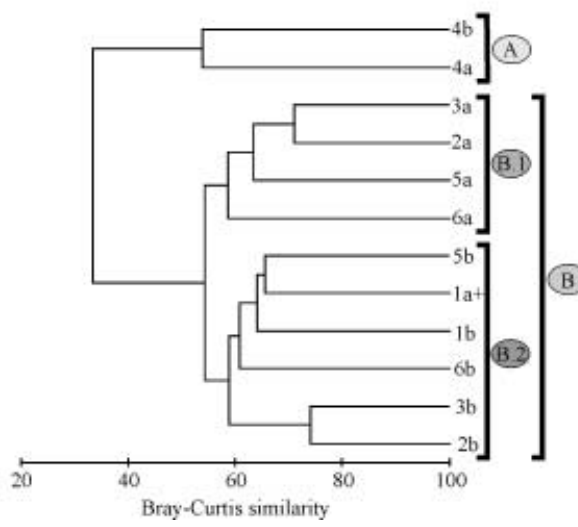

IV

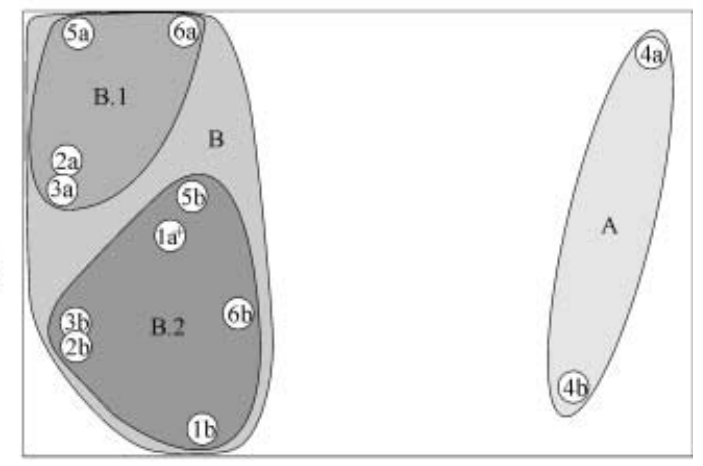

Table 5 Significance tests for diversity, species richness and abundance of fish assemblages at sites along the Jordanian Red Sea coast, Gulf of Aqaba (*0.05 $\geq p \geq 0.01$,

$* * 0.01>p \geq 0.001, * * * p<0.001$, $\log (1+x)$ represents $\log (1+x)$ transformed data, i.v. inhomogenous variances, n.s. not significant, coral coral reef, seagrass seagrass meadow)

$\begin{array}{lllll}6 \mathrm{~m} \text { vs } 12 \mathrm{~m} & \begin{array}{l}6 \mathrm{~m} \text { vs } 12 \mathrm{~m} \\ \text { (seagrass) }\end{array} & \begin{array}{l}6 \mathrm{~m} \text { vs } 12 \mathrm{~m} \\ \text { (coral) }\end{array} & \begin{array}{l}6 \mathrm{~m} \text { (seagrass) } \\ \text { vs } 6 \mathrm{~m} \text { (coral) }\end{array} & \begin{array}{l}12 \mathrm{~m} \text { (seagrass) } \\ \text { vs } 12 \mathrm{~m} \text { (coral) }\end{array}\end{array}$

Diversity

\section{F-test}

$F$-test PV

$F$-test CV P 99\%

ANOVA

F

$P$

Significance level

Species richness

\section{F-test}

$F$-test PV

$F$-test CV P 99\%

ANOVA

F

$P$

Abundance

\section{F-test}

$F$-test PV

$F$-test CV P 99\%

ANOVA

F

Significance level i.v. i.v.

i.v. i.v.

1.831

3.910

3.643

0.067

n.s.

i.v.

i.v.

$\begin{array}{ll}1.863 & 1.639 \\ 2.120 & 3.910 \\ & \\ 285.488 & 0.445 \\ <0.001 & 0.510 \\ * * & \text { n.s. }\end{array}$

n.s.

$\log (1+x) \quad$ i.v.

1.843

1.149

2.865

3.910

97.409

$<0.001$

21.211

6.719

0.015

$*$
2.123

3.450

1.438

2.600

52.113

$<0.001$

19.706

$<0.001$

1.085

3.420

2.521

0.118

n.s.

***

1.920

3.420

i.v.

20.839

$<0.001$ 

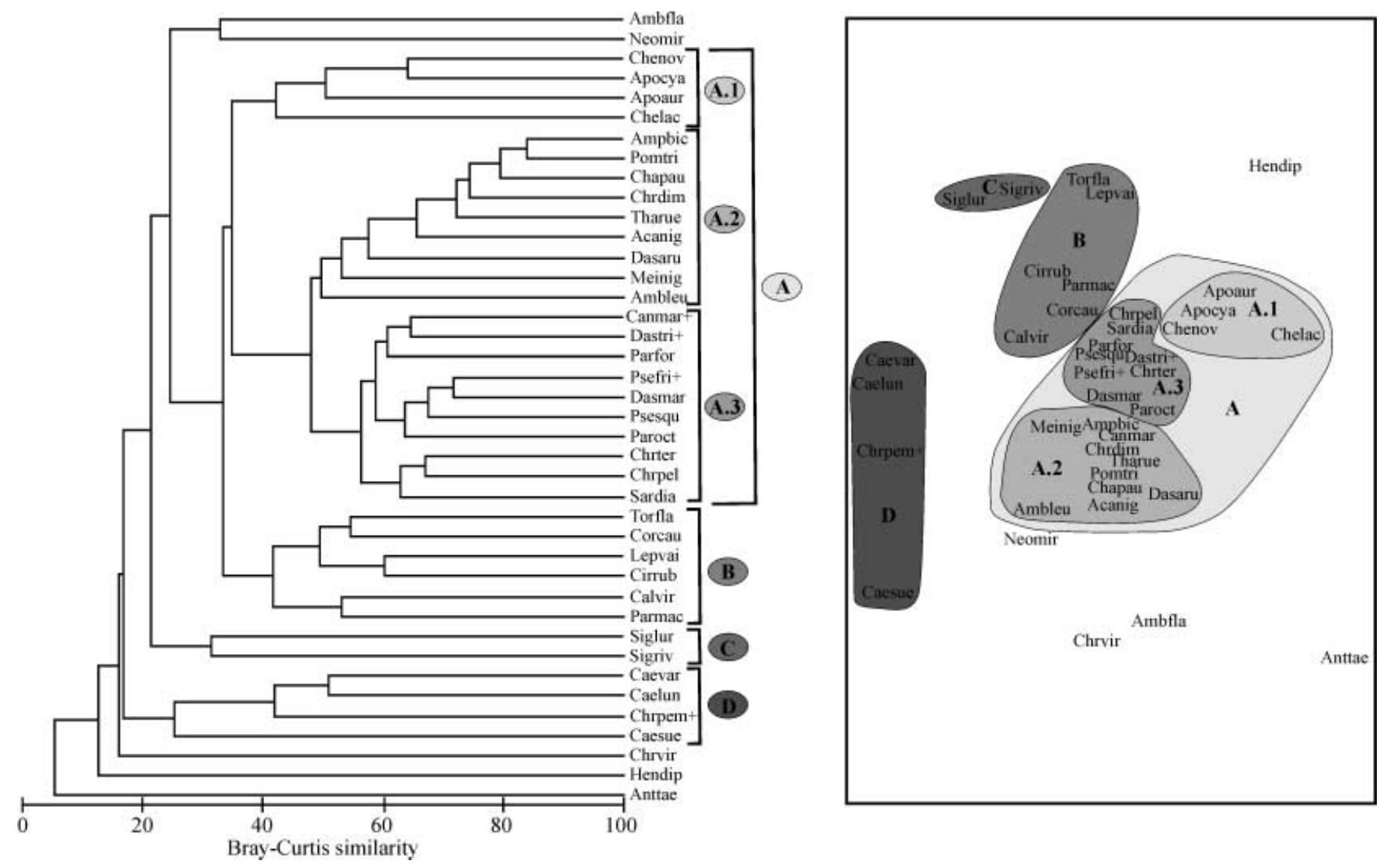

Fig. 5 Dendrogram (I) and MDS plot (II) of fish communities at the Jordanian Red Sea coast, Gulf of Aqaba. This analysis considers species with at least $0.2 \%$ of total abundance (no pelagic species, square root transformation of data, standardisation, group average, stress $=0.16)$. $A$ Fishes of coral reefs $(A .1$ Apogonidae, $A .2$ $6 \mathrm{~m}$ depth, $A .312 \mathrm{~m}$ depth). $B$ Fishes of seagrass meadows and sand flats. $C$ Siganidae. $D$ Caesionidae. Assignment of species to different depths reflects a higher relative abundance at this depth. + indicates mismatch. Species key: Acanig Acanthurus nigrofuscus, Ambfla Amblyglyphidodon flavilatus, Ambleu Amblyglyphidodon leucogaster, Ampbic Amphiprion bicinctus, Anttae Anthias taeniatus, Apoaur Apogon aureus, Apocya Apogon cyanosoma, Caelun Caesio lunaris, Caesue Caesio suevicus, Caevar Caesio varilineata, Calvir Calotomus viridescens, Canmar Canthi-

gaster margaritata, Chapau Chaetodon paucifasciatus, Chelac Cheilodipterus lachneri, Chenov Cheilodipterus novemstriatus, Chrdim Chromis dimidiata, Chrpel Chromis pelloura, Chrpem Chromis pembae, Chrter Chromis ternatensis, Chrvir Chromis viridis, Cirrub Cirrhilabrus rubriventralis, Corcau Coris caudimacula, Dasaru Dascyllus aruanus, Dasmar Dascyllus marginatus, Dastri Dascyllus trimaculatus, Hendip Heniochus diphreutes, Lepvai Leptoscarus vaigiensis, Meinig Meiacanthus nigrolineatus, Neomir Neopomacentrus miryae, Parfor Parupeneus forsskali, Parmac Parupeneus macronema, Paroct Paracheilinus octotaenia, Pomtri Pomacentrus trichourus, Psefri Pseudochromis fridmani, Psesqu Pseudanthias squamipinnis, Sardia Sargocentron diadema, Siglur Siganus luridus, Sigriv Siganus rivulatus, Tharue Thalassoma rueppellii, Torfla Torquigener flavimaculosus

Table 6 ANOSIM significance test on Bray-Curtis similarities of relationships between benthic habitats and between fish assemblages at sites along the Jordanian Red Sea coast, Gulf of Aqaba (no transformation or standardisation of data, coral coral-dominated sites, seagrass seagrass-dominated site, $* 0.05 \geq p \geq 0.01, * * 0.01>p \geq 0.001$, $* * * p<0.001$, n.s. not significant)

\begin{tabular}{lcccc}
\hline & $6 \mathrm{~m}$ vs $12 \mathrm{~m}$ & $\begin{array}{l}6 \mathrm{~m} \text { vs } 12 \mathrm{~m} \\
\text { (coral) }\end{array}$ & $\begin{array}{l}6 \mathrm{~m} \text { vs } 12 \mathrm{~m} \\
\text { (seagrass) }\end{array}$ & $\begin{array}{c}\text { Coral vs } \\
\text { seagrass }\end{array}$ \\
\hline Benthic habitat & & & & \\
Global $R$ & 0.053 & 0.123 & -0.185 & 0.754 \\
$P$ & 0.064 & 0.021 & 0.600 & $<0.001$ \\
Significance level & n.s. & $*$ & n.s. & $* * *$ \\
Fish assemblages & & & & \\
Global $R$ & 0.345 & 0.255 & 0.455 & 0.144 \\
$P$ & $<0.001$ & $<0.001$ & $<0.001$ & $<0.001$ \\
Significance level & $* * *$ & $* * *$ & $* * *$ & $* * *$ \\
\hline
\end{tabular}


MDS is an exploratory tool for the identification of typical fish communities of a certain habitat. Due to the high number of species and abundance it was difficult to distinguish these groups a priori. Therefore, an ANOSIM significance test was not conducted, because it only applies to groups of samples specified prior to seeing or collecting the data.

Correlation of fish community pattern to the benthic habitat

The BIO-ENV procedure of the PRIMER-5 software was used to correlate the fish community pattern to the benthic habitat (Table 7). The maximum correlation $(r=0.703$, weighted Spearman rank correlation) was obtained with the seagrass cover, followed by the combination of seagrass cover and depth $(r=0.677)$, and the combination of seagrass, depth and live coral cover $(r=0.579)$.

Fish species richness was positively linked to hard substrate cover by a power regression $(r=0.6742$, $p<0.005)$ (Fig. 6). The coefficient of determination $\left(r^{2}\right)$ indicates that $45.5 \%$ of variation can be attributed to hard substrate cover. The relationship of fish species richness to habitat diversity showed a positive correlation in a power regression $(r=0.7064, p<0.005)$ as well (Fig. 6). The analysis revealed that $r^{2}$ can assign $49.9 \%$ of variation to habitat diversity. A linear regression of abundance of corallivores in relation to live coral cover resulted in a positive correlation $(r=0.6956, p<0.005)$. In this case the $r^{2}$ indicates that $48.4 \%$ of variation can be attributed to live hard coral cover.

\section{Biogeography}

Cluster analysis and MDS plot revealed four main groups (Fig. 7): (1) Arabian Gulf, (2) Indian Ocean, (3) Red Sea, and (4) Southern Arabia. Differences in the grouping of the Southern Arabian cluster can be observed between the multivariate methods used in this analysis. On the one hand, the Southern Arabia cluster shows the lowest similarity to all other sites in the analysis based on Bray-Curtis similarity. On the other hand, the Euclidian distance revealed a high similarity to the Red Sea cluster. However, both MDS plots show a very similar pattern, where the Red Sea and Southern Arabian sites are situated between the Arabian Gulf and Indian Ocean sites.
The dendrogram suggested subgroups within the Red Sea, but neither MDS plot nor ANOSIM significance test confirmed this pattern, although ANOSIM gave evidence for the main groups (Table 8). However, ANOSIM
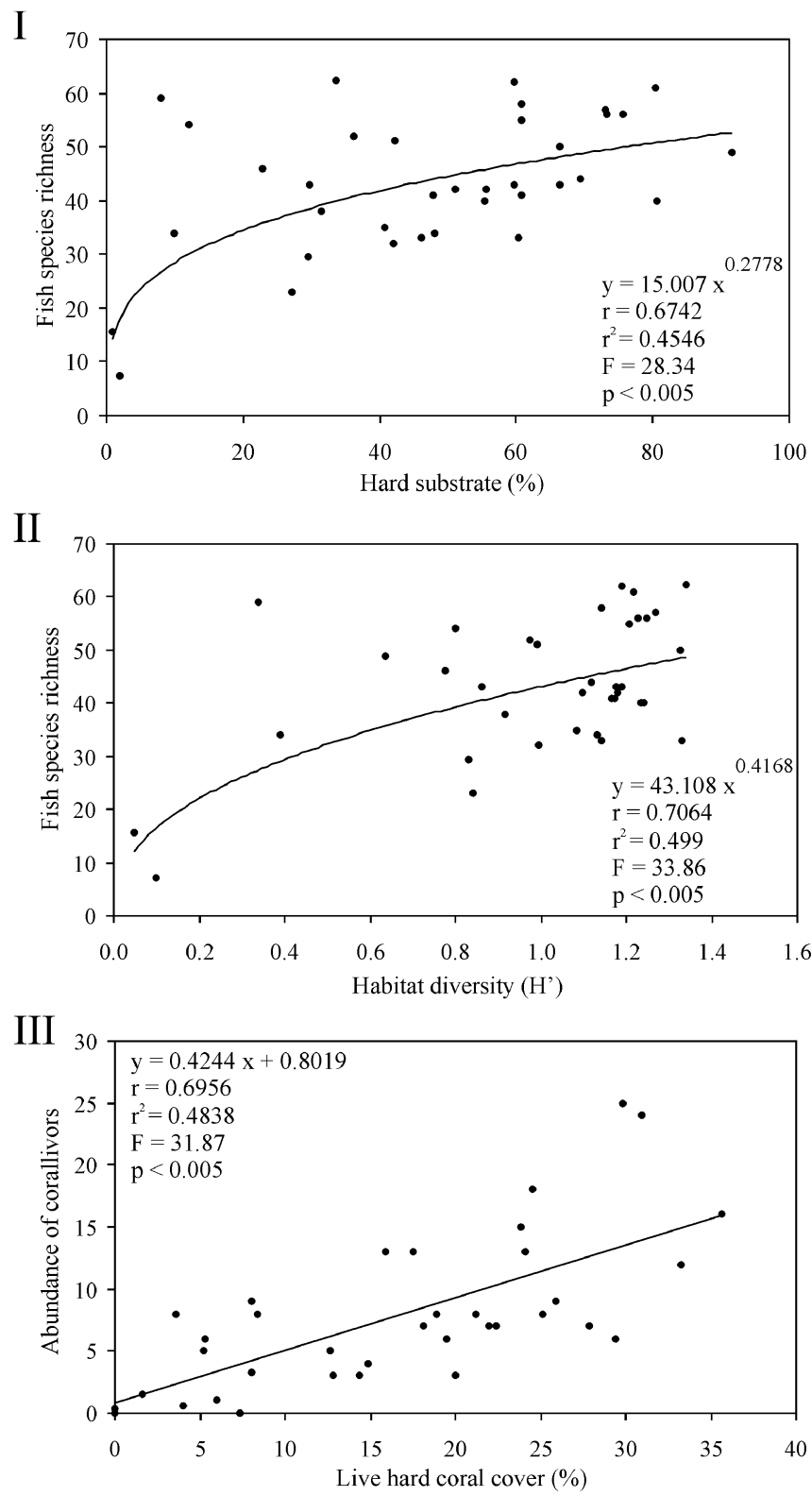

Fig. 6 Relationship of I fish species richness to benthic hard substrate cover and II to habitat diversity, as well as III abundance of corallivores to live hard coral cover at the Jordanian Red Sea coast, Gulf of Aqaba
Table 7 Correlation of fish community pattern to the benthic habitat (BIO-ENV, weighted Spearman rank correlation); $L C$ live hard coral, $S C$ live soft coral, $D C$ dead coral and rock, $S G$ seagrass, $S$ sand, $D$ depth, $k$ number of variables combined

\begin{tabular}{|c|c|c|c|c|c|c|}
\hline \multirow{3}{*}{$\frac{k}{1}$} & \multicolumn{6}{|c|}{ Best variable combinations and weighted Spearman rank correlation } \\
\hline & SG & $\mathrm{LC}$ & $\mathrm{DC}$ & $\mathrm{D}$ & $\mathrm{S}$ & SC \\
\hline & 0.703 & 0.280 & 0.241 & 0.224 & 0.035 & -0.094 \\
\hline \multirow[t]{2}{*}{2} & SG+D & SG+LC & $\mathrm{SG}+\mathrm{S}$ & $\mathrm{SG}+\mathrm{DC}$ & $\mathrm{SG}+\mathrm{SC}$ & $\mathrm{LC}+\mathrm{D}$ \\
\hline & 0.677 & 0.506 & 0.488 & 0.459 & 0.385 & 0.286 \\
\hline \multirow[t]{2}{*}{3} & $\mathrm{SG}+\mathrm{D}+\mathrm{LC}$ & $\mathrm{SG}+\mathrm{D}+\mathrm{DC}$ & $\mathrm{SG}+\mathrm{D}+\mathrm{S}$ & $\mathrm{SG}+\mathrm{T}+\mathrm{SC}$ & $\mathrm{SG}+\mathrm{LC}+\mathrm{S}$ & $\mathrm{SG}+\mathrm{LC}+\mathrm{DC}$ \\
\hline & 0.579 & 0.528 & 0.507 & 0.491 & 0.458 & 0.439 \\
\hline
\end{tabular}


Fig. 7 Map I, dendrogram and MDS plot based on Bray-Curtis similarity (stress $=0.09$ ) $\mathbf{I I}$ and Euclidean distance (stress = 0.06) III of biogeographic relationships between coastal fish assemblages of the Red Sea, Gulf of Aden, Indian Ocean and Arabian Gulf (Bray-Curtis similarity and Euclidean distance based on presence/absence of 712 species); proposed biogeographic borders after Klausewitz $(1978,1989)$ and (Kemp 1998): $a$ border between Indian Ocean and Gulf of Aden/Southern Arabia, $b$ border between Arabian Gulf and southern Arabia, $c$ border between Gulf of Aden and Red Sea (see discussion about location), $d$ barrier in the southern Red Sea at $20^{\circ} \mathrm{N}, e$ Gulf of Aqaba (also see Fig. 1)
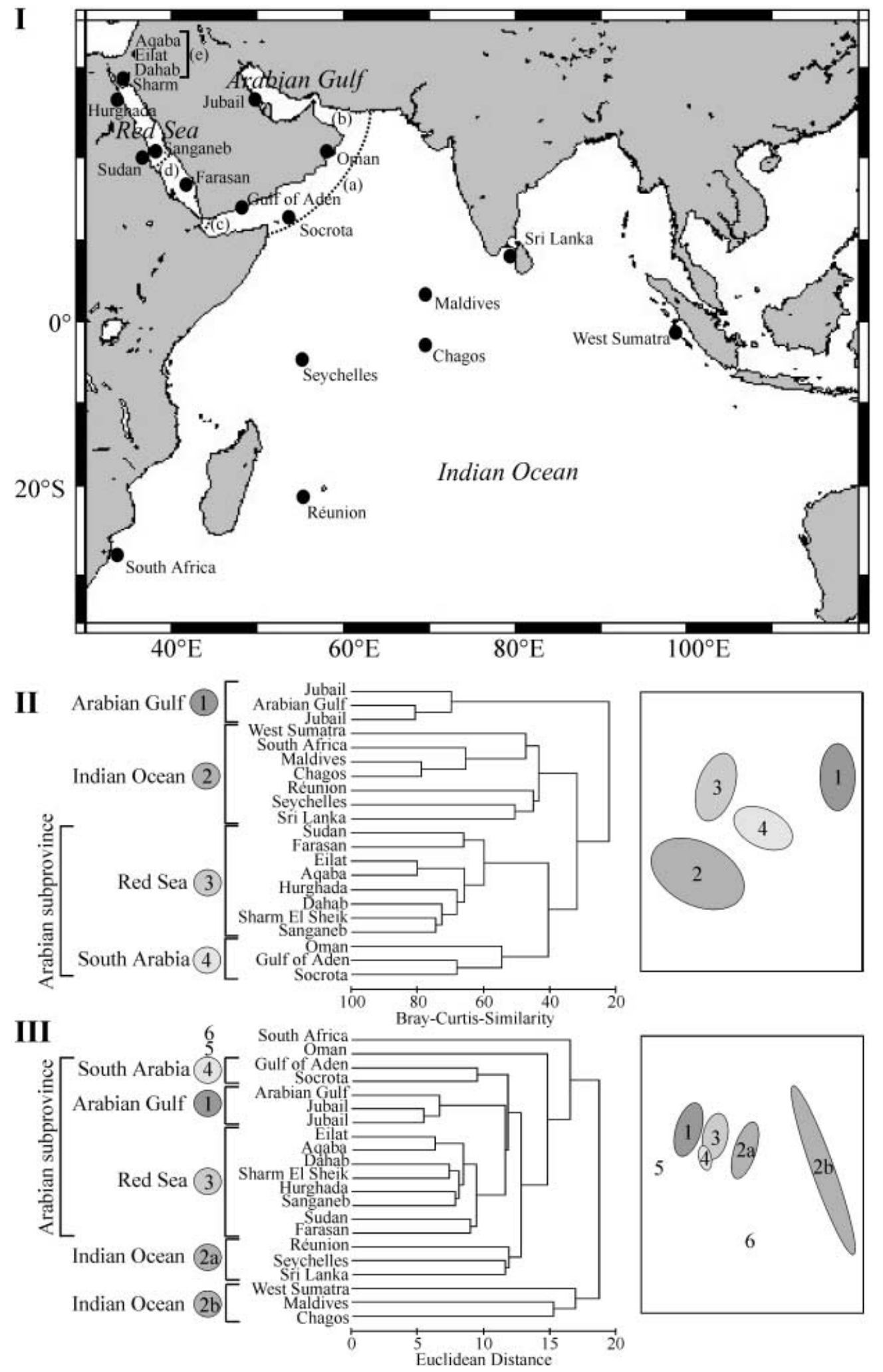

based on Bray-Curtis similarity showed a significant difference between the Arabian Gulf and all other sites, whereas analysis based on Euclidian distance was not significant. On the one hand, the Arabian Gulf shares $55.3 \%$ of its species with the Indian Ocean, whereas only
$45.6 \%$ of its species occur in the Red Sea. On the other hand, $75.4 \%$ of the Red Sea species have an Indian Ocean distribution, but the Red Sea shares only $22.7 \%$ of its species with the Arabian Gulf. 
Table 8 ANOSIM significance test on Bray-Curtis similarities $(B C S)$ and Euclidean distance $(E D)$ for biogeographic relationships. $* 0.05 \geq p \geq 0.01, * * 0.01>p \geq 0.001, * * * p<0.001$, n.s. not significant

\begin{tabular}{llllll}
\hline & $\begin{array}{l}\text { Red Sea vs } \\
\text { Southern Arabia }\end{array}$ & $\begin{array}{l}\text { Red Sea vs } \\
\text { Indian Ocean }\end{array}$ & $\begin{array}{l}\text { Red Sea vs } \\
\text { Arabian Gulf }\end{array}$ & $\begin{array}{l}\text { Gulf of Aqaba vs } \\
\text { Red Sea proper }\end{array}$ & $\begin{array}{l}\text { Arabian Gulf vs Red Sea, } \\
\text { Southern Arabia and Indian Ocean }\end{array}$ \\
\hline BCS & & & & & 0.787 \\
Global $R$ & 0.992 & 0.993 & 1.000 & 0.323 & 0.001 \\
$P$ & 0.006 & 0.001 & 0.006 & 0.125 & $* *$ \\
Significance level & $* *$ & $* *$ & $* *$ & n.s. & -0.037 \\
ED & & & & & 0.548 \\
Global $R$ & 0.914 & 0.616 & 0.987 & 0.169 & n.s. \\
$P$ & 0.006 & 0.001 & 0.006 & 0.161 & n.s. \\
Significance level & $* *$ & $* *$ & $* *$ & & \\
\hline
\end{tabular}

\section{Discussion}

All our conclusions are restricted to day-active and noncryptic species. As discussed by Brock (1982), dwarf, cryptic and nocturnal species are underestimated by the visual census technique. The visual census technique is widely applied and accepted for fish ecological studies on coral reefs (English et al. 1994), although differences in skill and technique of observers can be a source of imprecision and/or bias (Thompson and Mapstone 1997). Therefore the first author (M.A. Khalaf) conducted all censuses himself to avoid this problem. In the Jordanian waters of the Gulf of Aqaba, 348 species of fish have been recorded to date, with around 294 species occurring in shallow-water habitats such as coral reefs, seagrass meadows and sand flats (Khalaf and Disi 1997). In this study, approximately two-thirds (198 species) of the ichthyofauna at the Jordanian coast are considered for the analysis of shallow-water fish communities. In many other studies the investigations are restricted to certain families or subsets of the fish community, and the percentage of species considered for the analysis is not known.

Shore fish communities at the Jordanian Red Sea coast

\section{Dominant taxa and fish community parameters}

Pseudanthias squamipinnis is the most abundant species on Jordanian coral reefs as well as in the "Japanese gardens", off Eilat (Rilov and Benayahu 2000), at Nuweiba (Ben-Tuvia et al. 1983) and at Sanganeb atoll (Krupp et al. 1993). Other species making up more than $1 \%$ of total abundance in Jordan as well as at Sanganeb atoll are Chromis dimidiata and Chromis ternatensis. The following species belong to the ten most abundant species at both sides of the northern end of the Gulf of Aqaba ("Japanese gardens" and sites in Jordan): Pomacentrus trichourus, Paracheilinus octotaenia, Chromis dimidiata, Dascyllus marginatus and Neopomacentrus miryae (Table 4). As expected, the fish assemblages along the Jordanian and Israeli coasts are very similar.
On Indo-Pacific coral reefs, labrid and pomacentrid species are the dominant fishes (Table 3). Labridae (wrasse) contribute the highest percentage of species, followed by Pomacentridae (damselfish). The fish fauna on coral reefs in the Arabian Gulf shows a different composition, probably due to unfavourable environmental conditions for many tropical fish species. Two studies in the Caribbean revealed two main differences from the Indo-Pacific: a lower percentage of Labridae and a very high percentage of Serranidae (Table 3). However, comparisons have to be treated with caution, especially for rather cryptic families such as Gobiidae, Blenniidae and Scorpaenidae.

In terms of relative abundance of families, the ichthyofauna of the Jordanian coast is dominated by Pomacentridae, followed by Anthininae (subfamily of Serranidae) and Labridae. Visual censuses of fish assemblages on coral reefs in New Caledonia (Rossier and Kulbicki 2000) and on the Great Barrier Reef (Ackerman and Bellwood 2000) revealed the dominance of Pomacentridae as well. In New Caledonia the second most abundant family was Lutjanidae, followed by Chaetodontidae, Labridae and Apogonidae (Rossier and Kulbicki 2000). On the Great Barrier Reef the ranking after the dominant pomacentrids was Gobiidae, Caesionidae, Apogonidae, Labridae and Chaetodontidae (Ackerman and Bellwood 2000). Several families, such as Lutjanidae (three species), Haemulidae (four species) and Ephippidae (one species) are very rare along the Jordanian Red Sea coast (Khalaf and Disi 1997), but can be frequently observed in the Red Sea proper and other parts of the Indo-Pacific.

Shannon-Wiener diversity $\left(H^{\prime}\right)$ did not differ significantly between depths or between coral- and seagrassdominated sites (Fig. 3). Comparisons with other studies do not give a clear picture of an influence of depth on diversity $\left(H^{\prime}\right)$. On the one hand, Friedlander and Parrish (1998) pointed out a weak positive correlation between diversity $\left(H^{\prime}\right)$ and depth, which explained around $20 \%$ of the variation. On the other hand, Öhman and Rajasuriya (1998) did not find a significant correlation between diversity $\left(H^{\prime}\right)$ and depth. 
On the one hand, species richness was rather similar at the two depths of the coral reefs. This picture is in contrast to the general trend of species richness increasing with depth, shown for the Red Sea (Edwards and Rosewell 1981; Roberts and Ormond 1987), in Sri Lanka (Öhman and Rajasuriya 1998), and in Hawaii (Friedlander and Parrish 1998). However, this trend is most pronounced between $1 \mathrm{~m}$ and $6 \mathrm{~m}$ depths, with a smaller or no difference between $6 \mathrm{~m}$ and $12 \mathrm{~m}$ depths (Roberts and Ormond 1987). One or another of our study sites might show this difference as well (e.g. Tourist Camp), but the overall pattern does not support a significant difference between $6 \mathrm{~m}$ and $12 \mathrm{~m}$ depth. On the other hand, the seagrass-dominated site showed a significantly higher species richness at $12 \mathrm{~m}$ depth. This pattern might be generated by a higher percentage of hard substrate at $12 \mathrm{~m}$ depth, which provides more three-dimensional structures with holes for shelter. In a study of Roberts and Ormond (1987), the number of holes in a coral reef accounted for $77 \%$ of the variance in fish abundance, and Friedlander and Parrish (1998) attributed 73\% of the variance in fish biomass to the mean hole volume. Due to the lack of shelter at $6 \mathrm{~m}$ depth at Al-Mamlah Bay, the species richness is reduced relative to coral reefs at the same depth. Comparison of seagrass meadow and coral reefs at $12 \mathrm{~m}$ depth revealed the opposite picture, with a higher number of species and higher abundance in the seagrass.

The higher species richness and abundance in $12 \mathrm{~m}$ depth can be explained by the high productivity of the seagrass meadows and by feeding migrations of fishes from the coral reef to the seagrass beds (Ogden 1980; Robblee and Ziemann 1984; Quinn and Ogden 1984; Kochzius 1999). Invertebrate feeders are significantly more abundant at the seagrass-dominated site (M.A. Khalaf and M. Kochzius, unpublished data), where they can utilise the rich crustacean fauna. Nocturnal feeding migrations of invertebrate feeders from coral reefs into seagrasses are documented for the Atlantic as well as the Indo-Pacific (Weinstein and Heck 1979; Bell and Pollard 1989; Kochzius 1999). Studies in the Caribbean have shown that the biomass of fishes in coral reefs adjacent to seagrass meadows is higher than in reefs without seagrass beds (Birkeland 1985). Comparison of fisheries from different coral reef regions suggests that coral reefs bounded by extended shallow-water habitats, such as seagrass meadows or mangroves, yield the highest catch. Reefs with a ratio of shallow-water habitat to coral reef of 1:1 or more are very productive (Marshall 1985). Despite the lack of biomass data in this study, the high abundance of fishes in Al-Mamlah Bay supports these findings. Before the recent closing of this area, it was a favourite fishing ground for local fishermen, indicating a high standing stock and high productivity of fish. These results support the importance of Al-Mamlah Bay as a high productive area along the Jordanian Red Sea coast. A comparison of six seagrass meadows along the Jordanian coast revealed the highest seagrass biomass $\left(\mathrm{g} / \mathrm{m}^{3}\right)$ at Al-Mamlah Bay (Wahbeh 1981).
The overall picture shows a significantly lower abundance of fishes at $6 \mathrm{~m}$ depth than at $12 \mathrm{~m}$ depth (Fig. 3, Table 5). At the seagrass-dominated Al-Mamlah Bay this pattern can be explained by the lack of shelter at $6 \mathrm{~m}$ depth. At the coral-dominated sites, this difference is due to the high abundance of Pseudanthias squamipinnis and other planktivores at $12 \mathrm{~m}$ depth at all sites (Table 4). Pseudanthias squamipinnis accounts for $24.1 \%$ of the total abundance and feeds in large schools on zooplankton at sites exposed to the current. On the Jordanian coast planktivorous fishes are significantly more abundant at $12 \mathrm{~m}$ depth than at $6 \mathrm{~m}$ depth (M.A. Khalaf and M. Kochzius, unpublished data). The $12 \mathrm{~m}$ transects are more exposed to currents bringing zooplankton from offshore waters into the reef. A positive correlation of abundance as well as biomass of planktivores and depth was reported by Friedlander and Parrish (1998), but total fish abundance did not reveal a connection to depth as well. Investigations on herbivorous fishes, such as Acanthuridae (surgeonfish), Scaridae (parrotfish) and Siganidae (rabbitfish), on a coral reef in Aqaba suggests a higher abundance of these families at $10 \mathrm{~m}$ depth than at $5 \mathrm{~m}$ depth (Bouchon-Navaro and Harmelin-Vivien 1981).

The analysis of the dominant taxa and fish community parameters revealed the following pattern: (1) Labridae and Pomacentridae dominated the ichthyofauna in terms of species richness in the Gulf of Aqaba as well as on other Indo-Pacific coral reefs, (2) Pomacentridae was the dominant family in terms of relative abundance, (3) in the observed range of $6 \mathrm{~m}$ and $12 \mathrm{~m}$ depth, fish diversity and species richness on coral reefs in Aqaba were not correlated to depth, (4) abundance of fishes was significantly higher at $12 \mathrm{~m}$ depth than at $6 \mathrm{~m}$ depth along the Jordanian Red Sea coast, and (5) the seagrass-dominated sites showed a significantly higher species richness and abundance at $12 \mathrm{~m}$ depth than the coral-dominated sites, probably due to the high productivity of the seagrass meadows.

\section{Multivariate analysis of the fish community}

Cluster analysis, MDS plot and ANOSIM indicate significant differences between the fish communities of the two different depths as well as the two different habitats (Fig. 4, Table 6). This pattern of the fish communities is correlated with the composition of the benthic habitat (Global $\rho=0.638, p=0.006$ ), suggesting that habitat composition as well as depth are the main factors that influence the composition of the fish assemblages. The multivariate BIO-ENV procedure reveals the best correlation of the fish community pattern to habitat parameters in seagrass cover $(r=0.70)$ and combinations of the parameters seagrass cover and depth $(r=0.68)$ as well as seagrass cover, depth and live hard coral $(r=0.58)$. ANOSIM indicates that the overall benthic habitat composition does not show a significant difference between $6 \mathrm{~m}$ and $12 \mathrm{~m}$ depth, whereas fish communities are sig- 
nificantly different. This pattern implies that fish community changes with depth are not caused by changes in habitat composition. However, coral reefs show a significant difference in benthic habitat composition at the two depths, suggesting that differences in fish assemblages between depths were connected to changes in the benthic habitat. Results from this study indicate that the fish communities of the shallow-water habitats along the Jordanian Red Sea coast are strongly influenced by the composition of the benthic habitat and by depth. These habitat and depth-specific differences in fish communities on tropical shallow-water habitats are supported by other studies, e.g. Öhman and Rajasuriya (1998) for coral and sandstone reefs, and Friedlander and Parrish (1998) for a coral reef.

\section{Correlation of the fish community parameters and benthic habitat}

Regression analysis of benthic habitat and fish community parameters has revealed significant linear and curvilinear correlation. Species richness of fishes is positively correlated to hard substrate cover (live hard coral, dead coral and rock) as well as to habitat diversity $\left(H^{\prime}\right)$ in a power regression. Hard substrate cover is a measure of habitat complexity. A high hard substrate cover provides more shelter and food than a low hard substrate cover. A positive relationship of three-dimensional structure of the coral reef to fish community parameters has been demonstrated in many studies (Risk 1972; Talbot and Goldman 1972; Luckhurst and Luckhurst 1978; Gladfelter et al. 1980; Carpenter et al. 1981; Roberts and Ormond 1987; McClanahan 1994; Ormond et al. 1996; Chabanet et al. 1997; Friedlander and Parrish 1998; Lindahl et al. 2001) and accounts for $45 \%$ of the variance in fish species richness on coral reefs in the Gulf of Aqaba. Species richness is also positively correlated with habitat diversity $\left(H^{\prime}\right)$ (Roberts and Ormond 1987), and can explain nearly $50 \%$ of the variance in fish species richness. Habitat diversity $\left(H^{\prime}\right)$ is a measure for the heterogenity as well as patchiness of the habitat and higher values of $H^{\prime}$ indicate a higher heterogeneity or patchiness. The architectural property of heterogeneous or patchy habitats fosters diversity by allowing coexistence through microhabitat diversification and by increasing survival through provision of a refuge from predation (Heck and Orth 1980; Salita 2001).

Live hard coral cover was positively correlated with the abundance of corallivorous fishes and accounted for $48 \%$ of the variance in abundance. This strong relationship has been shown in several studies of corallivorous fishes (Bouchon-Navaro et al. 1985; Jennings et al. 1996; Öhman and Rajasuriya 1998), Chaetodontidae in general (Bell et al. 1985; Bouchon-Navaro and Bouchon 1989) and the complete fish community in regard to abundance, species richness and diversity (Bell and Galzin 1984; Carpenter et al. 1981; Harmelin-Vivien 1989; Chabanet et al. 1997; Adjeroud et al. 1998). An experimental disturbance of hard corals resulted in a significant reduction in abundance of chaetodontid fishes (Lewis 1997). However, there are also studies that found only a weak correlation between live coral cover for corallivores (Friedlander and Parrish 1998) and Chaetodontidae (Roberts et al. 1988) or even no correlation at all (Luckhurst and Luckhurst 1978; Roberts and Ormond 1987). The discrepancy between the different studies may have several reasons. Jennings et al. (1996) stated that "resident obligate corallivores will be absent if sites without coral cover are included, but this does not suggest that coral cover limits abundance in areas where coral is present". Jones and Syms (1998) discussed this problem in more detail and conclude that these discrepancies between studies are due to different ranges of observed coral cover. None of the studies examined the whole range of coral cover from $0 \%$ to $100 \%$ and therefore the nature, e.g. linear, curvilinear or unimodal, of the relationship is not known. The assumed linear relationships in the studies mentioned above are likely to be subsets of a more complex pattern, because very few ecological parameters follow linear patterns indefinitely (Jones and Syms 1998). In our study we analysed the relationship of abundance of corallivores to live hard coral cover in a range of $0 \%$ to $35 \%$ and a linear regression revealed the best fit. It is likely that the availability of hard corals as a source of food is the limiting factor for the abundance of corallivores in this particular range of live hard coral cover. However, it is possible that above a certain percentage of live hard coral cover this is no longer the main limiting factor, and other factors, such as competition between corallivorous fishes, may governs their abundance. Coral-feeding Chaetodontidae defend their territories against competitors, in some species intraspecific, in others also interspecific (Kosaki 1991; Wrathall et al. 1992; Righton et al. 1998). On the other hand, Connell (1978) has demonstrated that species richness of hard coral assemblages decreases with increasing live hard coral cover and Aronson and Precht (1995) showed that at sites with low levels of disturbance only a few coral species dominate the community. Therefore corallivorous fishes might be limited in their food source, because some chaetodontid species prefer or even feed only on a few species of coral (Reese 1977; Bouchon-Navaro 1986).

Another limitation, and possibly one reason for the differences in the studies on relation of fishes to habitat, is the assumption of the regression models that the habitat parameters are independent of the fish community. Corallivores and herbivores have an influence on the habitat by their feeding activity and there are also inter- and intraspecific interactions within the fish community (Roberts and Ormond 1987; Öhman and Rajasuriya 1998).

In summary our analysis of the correlation between fish community and benthic habitat revealed that (1) fish species richness is positively linked to hard substrate cover as well as habitat diversity, and (2) the abundance of corallivorous fishes is positively linked to live hard coral cover in our range of observation from $0 \%$ to $35 \%$. 


\section{Fish associations of shallow-water habitats}

The multivariate analysis of the fish community revealed several associations of fishes in different habitats. Within the large group of mainly coral-reef-associated fishes we can distinguish (1) a group of species that occur mainly at $6 \mathrm{~m}$ depth at the shallow reef slope, (2) a group that has a higher relative abundance at $12 \mathrm{~m}$ depth at the deep reef slope and (3) the Apogonidae (cardinalfish). Within the first group it is interesting to note that Chaetodon paucifasciatus is assigned to the upper reef slope, whereas in the Red Sea proper this species occurs in deeper water. Also several other species commonly occur in shallow water in the Gulf of Aqaba, e.g. Apolemichthys xanthotis (angelfish), Genicanthus caudovittatus (angelfish), Chromis pembae (damselfish), Pseudochromis fridmani (dottybacks), and Canthigaster coronata (tobies). It is suggested that this pattern could be due to lower surface temperatures in the Gulf of Aqaba (Edwards and Rosewell 1981; Ormond and Edwards 1987; Sheppard et al. 1992). However, this hypothesis remains conjectural and other explanations such as niche expansion in the absence of certain competitor species are also possible (Sheppard et al. 1992).

Other studies have revealed a similar pattern of a different species composition at the shallow and deep slope (McGehee 1994; Friedlander and Parrish 1998). McGehee (1994) assigned the difference to greater water movement in the shallow reef slope, but that study compared 2-4 $\mathrm{m}$ depth to a maximum of $10 \mathrm{~m}$ depth and it is therefore difficult to compare this with our results. At the Jordanian coast it seems more likely that the onshore transport of zooplankton is a factor that triggers the differences in occupation between the shallow and deep reef slope. The species group at the shallow reef slope contains only two planktivorous species, the non-schooling pomacentrids Chromis dimidiata and Amblyglyphidodon leucogaster. In contrast, the fish group at the deep reef slope comprises four planktivores, the solitary Chromis ternatensis (Pomacentridae) as well as the schooling species Pseudanthias squamipinnis (Serranidae), Paracheilinus octotaenia (Labridae) and Chromis pelloura (Pomacentridae). As discussed earlier, Pseudanthias squamipinnis showed a higher abundance at the current exposed deeper reef slope. In general, the abundance of planktivorous fish was significantly higher at $12 \mathrm{~m}$ depth than at $6 \mathrm{~m}$ depth (M.A. Khalaf and M. Kochzius, unpublished data). It has to be mentioned that Chromis pelloura was recorded only at the seagrassdominated site and therefore is an exception in the fish group regarded as typical for deep reef slope sites. However, this species showed the highest abundance at $12 \mathrm{~m}$ depth and is therefore assigned to this group of deep reef slope species.

The third group of coral-reef-associated fishes are apogonid species. Members of the family Apogonidae are nocturnally active species that hide in the daytime e.g. in crevices or between spines of sea urchins. A study in the Philippines has shown that apogonid species, such as Apogon aureus and Apogon cyanosoma, seek shelter in the coral reef during the day and migrate at night into adjacent seagrass meadows to forage (Kochzius 1999). Members of this family utilise the same habitat for shelter and are therefore grouped together.

Another association of fishes are species of seagrass meadows and sandflats, such as the scarid Leptoscarus vaigiensis which is known as a resident species in seagrass meadows (Randall 1983; Kochzius 1999). The scarid Calotomus viridescens is most commonly seen in seagrass meadows, but also occurs on coral reefs or rocky substrate (Randall 1983). Calotomus viridescens is endemic to the Red Sea and in the Indo-West Pacific the niche of this species seems to be occupied by Calotomus spinidens (Kochzius 1999). The labrids Cirrhilabrus rubriventralis and Coris caudimacula are inhabitants of seagrass meadows as well as areas of mixed sand, rubble, rocks and corals (Randall 1983; Khalaf and Disi 1997). The mullid Parupeneus macronema is a feeder on benthic invertebrates of sandy areas and juveniles are associated with seagrass meadows (Khalaf and Disi 1997). Torquigener flavimaculosus (Tetraodontidae) is a typical species of shallow sand flat and rubble habitats (Khalaf and Disi 1997).

Two smaller groups of fish associations are the two siganid species, both feeding on benthic algae, and the three planktivorous species of the family Caesionidae, which usually school in mid-water (Khalaf and Disi 1997).

The fish communities of shallow-water habitats along the Jordanian Red Sea coast showed different assemblages of fishes (1) on the deep reef slope, (2) on the shallow reef slope and (3) on seagrass meadows and sand flats. In addition the analysis revealed ecological groups such as schooling herbivores, schooling planktivores and reefassociated apogonids.

\section{Biogeography}

The number of shore fish species in the Gulf of Aqaba is higher than previously reported. Sheppard et al. (1992) examined the species richness of the families Chaetodontidae (butterflyfish), Pomacentridae (damselfish), Labridae (wrasse), Acanthuridae (surgeonfish), Serranidae (groupers) and Scaridae (parrotfish) in different areas of the northern Red Sea, Gulf of Suez and Gulf of Aqaba. Their study showed a decrease in species richness from 100 species at the southern coast of Egypt in the Red Sea proper to 75 species in the northern Gulf of Aqaba. The results of our study and additional species lists from literature (Khalaf and Disi 1997; Rilov and Benayahu 2000) demonstrate that the species richness of these families in the northern Gulf of Aqaba is much higher and reaches 104 species. A list compiled from different sources indicates a total of 362 species of shore fishes for the Gulf of Aqaba (Ben-Tuvia et al. 1983; Khalaf and Disi 1997; Rilov and Benayahu 2000; M. Kochzius, personal observation: U. Zajonz et al., unpublished report; this study). 
In terms of shore fish species composition, there are significant differences between the Red Sea, Gulf of Aden, Arabian Gulf and Indian Ocean. The relationships of the ichthyofaunal composition based on presence/absence data from these localities showed a pattern of decreasing similarity of fish communities in the dendrogram from the northern Gulf of Aqaba through the Red Sea proper into the Indian Ocean (Fig. 7). This pattern could indicate a generalised track between the northern Red Sea and the southern Red Sea plus Indian Ocean (Winterbottom 1985).

Differences in the structure of fish communities on northern and southern Red Sea coral reefs are shown for several families, such as Chaetodontidae (butterflyfish), Pomacanthidae (angelfish), Pomacentridae (damselfish), Acanthuridae (surgeonfish), Scaridae (parrotfish), Labridae (wrasse), Lethrinidae (emperors), and Lutjanidae (snappers). Scleractinian corals as well show distinct changes in species richness from north to south, with a higher number of species in the central Red Sea (Roberts et al. 1992), and north-south differences in the community structure (Sheppard and Sheppard 1991). These differences in the community structure of fishes and corals within the Red Sea might be due to north-south differences in habitat as well as an abrupt increase in turbidity south of $20^{\circ} \mathrm{N}$ (Sheppard et al. 1992; Roberts et al. 1992).

Differences between Red Sea fish communities and fish assemblages of the Indian Ocean are caused by two barriers: On the one hand there is a barrier at the connection of the Red Sea to the Indian Ocean. Some authors regard the shallow sill of the Bab El Mandab strait as the barrier (Klausewitz 1989; Roberts et al. 1992), others locate it in the southern Red Sea (Blum 1989; Righton et al. 1996) or in the western Gulf of Aden (Kemp 1998). On the other hand there is the reef-free section between Somalia and India, separating the Red Sea from the Indian Ocean (Klausewitz 1978; Roberts et al. 1992). This lack of coral reefs is connected to a 'pseudo-high latitude effect', which results from seasonal cold water upwelling along the southern coast of the Arabian peninsula and the Indian Ocean coast of Somalia (Klausewitz 1989; Sheppard and Sheppard 1991; Kemp 1998).

Klausewitz $(1978,1989)$ regarded the ichthyofauna of the Arabian seas as a biogeographical sub-province, including the Red Sea, Gulf of Aden and Arabian Gulf. Further studies of chaetodontid species assemblages by cluster analysis support this view, grouping assemblages from Oman, Socrota and Arabian Gulf together in one cluster, more closely related to the Red Sea than to the Indian Ocean (Kemp 1998). An analysis of the Indian Ocean coral fauna based on presence/absence of species revealed a biogeographic Arabian sub-province as well (Sheppard and Sheppard 1991). However, our biogeographic analysis revealed a clear pattern of the faunal relationships between the Red Sea, Southern Arabia and the Indian Ocean, but the biogeographic affinity of the Arabian Gulf is not clear. The two dendrograms based on different coefficients revealed conflicting results and one dendrogram does not support the close affinity of the Arabian Gulf to the Red Sea.

There is no doubt that not all of the species lists used in this analysis are comprehensive and taxonomic error cannot be excluded. Nevertheless, multivariate statistics are very robust in regard to completeness of the data sets and clusters are stable up to an error of $10-20 \%$ (Sheppard 1998). Re-examination of the chaetodontid distribution data presented by Kemp (1998) using BrayCurtis analysis revealed the same pattern as our more comprehensive analysis based on Bray-Curtis similarity: the Arabian Gulf shows the lowest similarity to all other sites. Therefore the oppositional results are due to methodological problems of the cluster analysis, rather than to incomplete species lists or taxonomic error. There are gradual changes between the different areas, but cluster analysis forces gradual into stepwise changes. MDS plots are able to represent gradual differences and therefore the MDS plots based on Bray-Curtis similarity and Euclidean distance are very similar (Fig. 7). However, there are other arguments that support the view of a low similarity of the Arabian Gulf to the Red Sea. The Arabian Gulf shares more fish species from our data set with the Indian Ocean than with the Red Sea. Cluster analysis and MDS plot of absence/presence data of hermatypic corals revealed a closer relationship of the Red Sea to islands from the Central Indian Ocean than to the Arabian Gulf and Southern Arabia (Sheppard 1998). Studies on the zoogeographic relationships of grapsid and ocypodid crabs have revealed that most of the Arabian Gulf species are of an "eastern" Indian Ocean origin. In addition, species of an "western" Indian Ocean origin (East Africa and Red Sea) are absent from the northern and western Gulf (Kuwait and Saudi Arabia) (Apel and Türkay 1999). Reasons for these differences might be ecological rather than historical, because the Arabian Gulf and Red Sea have been recolonised from the same area after transgression of sea level about 17,000 years ago. The unfavourable oceanographic conditions for tropical species in the Arabian Gulf explain the relatively low species richness (Coles and Tarr 1990; Krupp and Almarri 1996).

Summarising the arguments mentioned above, the biogeographic analysis revealed the following pattern: (1) the species richness of fishes on coral reefs in the Gulf of Aqaba is much higher than previously reported, and (2) the Red Sea and southern Arabia are significantly different from other sites of the Indian Ocean, but the affiliation of the Arabian Gulf is not clear.

Our study has demonstrated that the shore fishes in the Gulf of Aqaba show a relatively high biodiversity. Due to urbanisation, industrialisation, shipping activity and tourism in the Gulf of Aqaba, the environment is under growing pressure. Management for the protection of the marine resources is therefore needed. Scientific programmes such as the Red Sea Program on Marine Sciences (RSP) and the Red Sea Marine Peace Park Project provide important baseline data for multinational research and conservation of the Gulf of Aqaba. Our re- 
sults on the ecological parameters which structure the shore fish communities give valuable information for the establishment of marine reserves at the Jordanian Red Sea coast. Beside the highly important coral reefs, adjacent habitats such as seagrass meadows should also be considered in the establishment of marine reserves.

Acknowledgements We would like to express our thanks to the foundations, institutions and to the individuals that have made our work possible: Director and staff of the Marine Science Station, Aqaba, Jordan, in particular O. Al-Momani; Aqaba Special Economic Zone Authority; Office of Ocean and Coastal Resource Management (OCRM/NOS, NOAA) and USAID; M. Crospy (NOOA); Red Sea Program on Marine Sciences (RSP), funded by the German Federal Ministry of Education and Research (BMBF, grant no. 03F0151A); Centre for Tropical Marine Ecology (ZMT), Bremen, Germany, in particular G. Hempel, C. Richter, P. Westhaus-Ekau and M. Birkicht; U. Zajonz (Senckenberg Research Institute, Germany), F. Krupp (PERSGA, Saudi Arabia), A.H. Abuzinada (NCWCD, Saudi Arabia) and J. Kemp (University of York, UK) for providing us with species lists. G. Hempel, F. Krupp and reviewers gave valuable comments on the manuscript.

\section{References}

Abelson A, Shteinman B, Fine M, Kaganovsky S (1999) Mass transport from pollution sources to remote coral reefs in Eilat (Gulf of Aqaba, Red Sea). Mar Pollut Bull 38:25-29

Abu-Hilal AH (1985) Phosphate pollution in the Jordan Gulf of Aqaba. Mar Pollut Bull 16:281-285

Abu-Hilal AH (1987) Distribution of trace elements in nearshore surface sediments from the Jordan Gulf of Aqaba (Red Sea). Mar Pollut Bull 18:190-193

Abu-Hilal AH, Badran MM (1990) Effect of pollution source on metal concentration in sediment cores from the Gulf of Aqaba. Mar Pollut Bull 21:190-197

Ackerman JL, Bellwood DR (2000) Reef fish assemblages: a reevaluation using enclosed rotenone stations. Mar Ecol Prog Ser 206:227-237

Adjeroud M, Letourneur Y, Porcher M, Salvat B (1998) Factors influencing spatial distribution of fish communities on a fringing reef at Mauritius, S.W. Indian Ocean. Environ Biol Fishes 53:169-182

Anderson RC, Randall JE, Kuiter RH (1998) New records of fishes from the Maldive Islands, with notes on other species. Ichthyol Bull JLB Smith Inst Ichthyol 67(2):20-32

Apel M, Türkay M (1999) Taxonomic composition, distribution and zoogeographic relationships of the grapsid and ocypodid fauna of intertidal soft bottoms in the Arabian Gulf. Estuar Coast Shelf Sci 49 [Suppl A]:131-142

Aronson RB, Precht WF (1995) Landscape patterns of reef coral diversity: a test of the intermediate disturbance hypothesis. J Exp Mar Biol Ecol 192:1-14

Backhaus K, Erichson B, Plinke W, Weiber R (1994) Multivariate Analysemethoden. Springer, Berlin Heidelberg New York

Badran MI, Foster P (1998) Environmental quality of the Jordanian coastal waters of the Gulf of Aqaba, Red Sea. Aquat Ecosyst Health Manage 1:75-89

Baranes A, Golani D (1993) An annotated list on deep-sea fishes collected in the northern Red Sea, Gulf of Aqaba. Isr J Zool 39:299-336

Bell JD, Galzin R (1984) Influence of live coral cover on coralreef fish communities. Mar Ecol Prog Ser 15:265-274

Bell JD, Pollard DA (1989) Ecology of fish assemblages and fisheries associated with seagrasses. In: Larkum AWD, McComb AJ, Shepherd SA (eds) Biology of seagrasses: a treatise on the biology of seagrasses with special reference to the Australian region. Elsevier, Amsterdam, pp 565-609
Bell JD, Harmelin-Vivien M, Galzin R (1985) Large scale spatial variation in abundance of butterflyfishes (Chaetodontidae) on Polynesian reefs. Proc 5th Int Coral Reef Congr 5:421-426

Ben-Tuvia A, Diamant A, Baranes A, Golani D (1983) Analysis of a coral reef fish community in shallow-waters of Nuweiba, Gulf of Aqaba, Red Sea. Bull Inst Oceanogr Fish 9:193-206

Birkeland C (1985) Ecological interactions between mangroves, seagrass beds, and coral reefs. In: Ecological interactions between tropical coastal ecosystems. (UNEP regional seas reports and studies 73) UNEP. Earthprint, Stevenage, UK, pp $1-65$

Blum SD (1989) Biogeography of the Chaetodontidae: an analysis of allopatry among closely related species. Environ Biol Fish 25:9-31

Bouchon-Navaro Y (1980) Quantitative distribution of the Chaetodontidae on a fringing reef of the Jordanian coast (Gulf of Aqaba, Red Sea). Tethys 9:247-251

Bouchon-Navaro Y (1986) Partitioning of food and space resources by chaetodontid fishes on coral reefs. J Exp Mar Biol Ecol 103:21-40

Bouchon-Navaro Y, Bouchon C (1989) Correlations between chaetodontid fishes and coral communities of the Gulf of Aqaba (Red Sea). Environ Biol Fish 25:47-60

Bouchon-Navaro Y, Harmelin-Vivien ML (1981) Quantitative distribution of herbivorous reef fishes in the Gulf of Aqaba (Red Sea). Mar Biol 63:79-86

Bouchon-Navaro Y, Bouchon C, Harmelin-Vivien ML (1985) Impact of coral degradation on a chaetodontid fish assemblage (Moorea, French Polynesia). Proc 5th Int Coral Reef Congr $5: 427-432$

Brock RE (1982) A critique of the visual census method for assessing coral reef fish populations. Bull Mar Sci 32:269-276

Bryant D, Burke L, McManus J, Spalding M (1998) Reefs at risk: a map-based indicator of threats to the world's coral reefs. World Resource Institute, Washington

Carpenter KE, Miclat RI, Albaladeho, VD, Corpuz, VT (1981) The influence of substrate structure on the local abundance and diversity of Philippine reef fishes. Proc 4th Int Coral Reef Symp Manila 2:497-502

Carpenter KE, Krupp F, Jones DA, Zajonz U (1997) Living marine resources of Kuwait, Eastern Saudi Arabia, Bahrain, Qatar, and the United Arab Emirates: FAO species identification field guide for fishery purposes. Rome, FAO

Chabanet P, Ralambondrainy H, Amanieu M, Faure G, Galzin R (1997) Relationships between coral reef substrata and fish. Coral Reefs 16:93-102

Clark E, Ben-Tuvia A, Steinitz H (1968) Observations on a coastal fish community, Dahlak Archipelago, Red Sea. Sea Fish Res Stn Haifa Bull 49:15-31

Clarke KR, Warwick RM (1994) Changes in marine communities: an approach to statistical analysis and interpretation. Natural Environment Research Council, Swindon, UK

Coles SL, Tarr AB (1990) Reef fish assemblages in the western Arabian Gulf: a geographically isolated population in an extreme environment. Bull Mar Sci 47:696-720

Connell JH (1978) Diversity in tropical rain forests and coral reefs. Science 199:1302-1309

Edwards A, Rosewell J (1981) Vertical zonation of coral reef fishes in the Sudanese Red Sea. Hydrobiologia 79:21-31

English C, Wilkinson C, Baker V (1994) Survey manual for tropical marine resources. Australian Institute of Marine Science, Townsville, Queensland

FishBase (1999) FishBase 99: a global information system on fishes. CD-ROM, ICLARM, Manila

Fishelson L, Popper D, Avidor A (1974) Biosociology and ecology of pomacentrid fishes around the Sinai Peninsula (northern Red Sea) J Fish Biol 6:119-133

Forsskål P (1775) Descriptiones animalium, avium, amphibiorum, piscium, insectorum, vermium; quae in itinere orientali observavit. Hauniae

Fricke HW (1977) Community structure, social organization and ecological requirements of coral reef fishes (Pomacentridae). Helgol Wiss Meeresunters 30:412-426 
Friedlander AM, Parrish JD (1998) Habitat characteristics affecting fish assemblages on a Hawaiian coral reef. J Exp Mar Biol Ecol 224:1-30

Gladfelter WB, Ogden JC, Gladfelter EH (1980) Similarity and diversity among coral reef fish communities: a comparison between tropical western Atlantic (Virgin Islands) and tropical central Pacific (Marshall Islands) patch reefs. Ecology 61:1156-1168

Golani D, Diamant A (1999) Fish colonization of an artificial reef in the Gulf of Eilat, northern Red Sea. Environ Biol Fish $54: 275-282$

Goren M, Dor M (1994) An updated checklist of the fishes of the Red Sea. CLOFRES II. The Israel Academy of Sciences and Humanities, Jerusalem

Harmelin-Vivien ML (1989) Reef fish community structure: an Indo-Pacific comparison. In: Harmelin-Vivien ML, Bourlière $\mathrm{F}$ (eds) Vertebrates in complex tropical systems. Springer, Berlin Heidelberg New York, pp 21-60

Harmelin-Vivien ML, Bouchon-Navaro Y (1981) Trophic relationships among chaetodontid fishes in the Gulf of Aqaba (Red Sea). Proc 4th Int Coral Reef Symp 2:537-544

Hawkins JP, Roberts CN (1994) The growth of coastal tourism in the Red Sea: present and future effects on coral reefs. Ambio 23:503-508

Heck KL, Orth RJ (1980) Seagrass habitats: the roles of habitat complexity, competition and predation in structuring associated fish and motile macroinvertebrate assemblages. In: Kennedy VS (ed) Estuarine perspectives. Academic Press, New York, pp 449-464

Hoeg-Guldberg O (1999) Climate change, coral bleaching and the future of the world's coral reefs. Mar Freshw Res 50:839866

Jennings S, Boullé DP, Polunin NVC (1996) Habitat correlates of the distribution and biomass of Seychelles' reef fishes. Environ Biol Fish 46:15-25

Jones GP, Syms C (1998) Disturbance, habitat structure and the ecology of fishes on coral reefs. Aust J Ecol 23:287-297

Kemp J (1998) Zoogeography of the coral reef fishes of the Socrota Archipelago. J Biogeogr 25:919-933

Kemp J (2000) Zoogeography of the coral reef fishes of the northeastern Gulf of Aden, with eight new records of coral reef fishes from Arabia. Fauna Arabia 18:293-321

Khalaf MA, Disi AM (1997) Fishes of the Gulf of Aqaba. Marine Science Station, Aqaba

Khalaf MA, Disi AM, Krupp F (1996) Four new records of fishes from the Red Sea. Fauna Saudi Arabia 15:402-406

Klausewitz W (1964) Die Erforschung der Ichthyofauna des Roten Meeres. In: Klunzinger CB (1870, reprint) Synopsis der Fische des Rothen Meeres. Cramer, Weinheim, pp v-xxxvi

Klausewitz W (1978) Zoogeography of the littoral fishes of the Indian Ocean, based on the distribution of the Chaetodontidae and Pomacanthidae. Senckenb Biol 59:25-39

Klausewitz W (1989) Evolutionary history and zoogeography of the Red Sea ichthyofauna. Fauna Saudi Arabia 10:310-337

Klunzinger CB (1884) Die Fische des Rothen Meeres. 1. Theil, Stuttgart

Kochzius M (1999) Interrelation of ichthyofana from a seagrass meadow and coral reef in the Philippines. In: Séret B, Sire J-Y (eds) Proceedings of the 5th Indo-Pacific Fish Conference (Nouméa, 3-8 November 1997). Société Française d'Ichthyologie and Institut de Recherche pou le Développement, Paris, pp 517-535

Kosaki RK (1991) Patterns of resource use and aggressive interactions among three species of coral-feeding butterflyfish (Chaetodontidae). Pac Sci 45(1):94

Krupp F, Almarri MA (1996) Fishes and fish assemblages of the Jubail marine wildlife sanctuary. In: Krupp F, Abuzinada AH, Nader IA (eds) A marine wildlife sanctuary for the Arabian Gulf. Environmental research and conservation following the 1991 Gulf war oil spill. NCWCD, Riyadh/Senckenberg Research Institute, Frankfurt, pp 339-350

Krupp F, Paulus T, Nasr D (1993) Coral reef fish survey. In: Krupp F, Türkay M, El Hag AGD, Nasr D (eds) Comparative ecological analysis of biota and habitats in littoral and shallow sublittoral waters of the Sudanese Red Sea. Project report. Forschungsinstitut Senckenberg, Frankfurt/Faculty of Marine Science and Fisheries, Port Sudan, pp 63-82

Krupp F, Müller T, Al-Sana'a M, Al-Marri M (1994) Survey of fishes and fish assemblages in Dawhat ad-Dafi, Dawhat alMusallamiya and the Gulf Coral Islands. In: Feltkamp E, Krupp F (eds) Establishment of a marine habitat and wildlife sanctuary for the Gulf region. Final report for phase II. Forschungsinstitut Senckenberg, Frankfurt, pp 537-558

Kunzmann A, Randall JE, Suprihanto I (1999) Checklist of the shore fishes of the Mentawai Islands, Nias Islands and the Padang region of West Sumatra. Naga 22(1): 4-10

Letourneur Y (1996) Dynamics of fish communities on Reunion fringing reefs, Indian Ocean. I. Patterns of spatial distribution. J Exp Mar Biol Ecol 195:1-30

Letourneur Y, Kulbicki M, Galzin R, Harmelin-Vivien M (1997) Comparaison des peuplements de poissons marins des récifs frangeants de trois îles océaniques de l'Indo-Pacifique (La Réunion, Moorea et la Nouvelle-Calédonie). Cybium 21 (1) [Suppl]:129-145

Lewis AR (1997) Effects of experimental coral disturbance on the structure of fish communities on large patch reefs. Mar Ecol Prog Ser 161:37-50

Lindahl U, Öhman M, Schelten CK (2001) The 1997/1998 mass mortality of corals: effects on fish communities on a Tanzanian coral reef. Mar Pollut Bull 42:127-131

Luckhurst BE, Luckhurst K (1978) Analysis of the influence of substrate variables on coral reef fish communities. Mar Biol 49:317-323

Marshall N (1985) Ecological sustainable yield (fisheries potential) of coral reef areas, as related to physiographic features of coral reef environments. Proc 5th Int Coral Reef Congr $5: 525-530$

McClanahan TR (1994) Kenyan coral reef lagoon fish: effects of fishing, substrate complexity, and sea urchins. Coral Reefs 13:231-241

McGehee MA (1994) Correspondence between assemblages of coral reef fishes and gradients of water motion, depth and substrate size off Puerto Rico. Mar Ecol Prog Ser 105:243255

Mergner H (1979) Quantitative ökologische Analyse eines Rifflagunenareals bei Aqaba (Golf von Aqaba, Rotes Meer). Helgol Wiss Meeresunters 32:476-507

Mergner H (2001) Riff-Forschung am Roten Meer. Naturwiss Rundschau 54(1):4-16

Mergner H, Schuhmacher H (1974) Morphologie, Ökologie und Zonierung von Korallenriffen bei Aqaba, (Golf von Aqaba, Rotes Meer). Helgol Wiss Meeresunters 26:238-358

Mergner H, Schuhmacher H (1981) Quantitative Analyse der Korallenbesiedlung eines Vorriffareals bei Aqaba (Rotes Meer). Helgol Meeresunters 34:337-354

Nielsen JG (1993) Peter Forsskål - a pioneer in Red Sea ichthyology. Isr J Zool 39:283-286

Ogden JC (1980) Faunal relationships in Caribbean seagrass beds. In: Phillips RC, McRoy CP (ed) Handbook to seagrass biology. Garland, New York, pp 173-198

Öhman MC, Rajasuriya A (1998) Relationships between structure and fish communities on coral and sandstone reefs. Environ Biol Fish 53:19-31

Öhman MC, Rajasuriya A, Ólafsson E (1997) Reef fish assemblages in north-western Sri Lanka: distribution patterns and influence of fishing practises. Environ Biol Fish 49:45-61

Ormond R, Edwards A (1987) Red Sea fishes. In: Edwards AJ, Head SM (eds) Key environments - Red Sea. Pergamon Press, Oxford

Ormond RFG, Roberts JM, Jan R-Q (1996) Behavioural differences in microhabitat use by damselfishes (Pomacentridae): implications for reef fish biodiversity. J Exp Mar Biol Ecol 202:85-95

Parrish JD (1989) Fish communities of interacting shallow-water habitats in tropical oceanic regions. Mar Ecol Prog Ser $58: 143-160$ 
Pattengill CV, Semmens BX, Gittings SR (1997) Reef fish structure at the Flower Gardens and Stetson Bank, NW Gulf of Mexico. Proc 8th Int Coral Reef Symp 1:1023-1028

Pittman SJ (1996) Coral reef fish assemblages of Baie Ternay National Marine Park and Baie Beau Vallon, Mahé, Seychelles. Draft report of the Seychelles Marine Parks Expedition 1995

Primer-E (2000) PRIMER 5 (Plymouth Routines in Multivariate Ecological Research). PRIMER-E, Plymouth Marine Laboratory, UK

Quinn TP, Ogden JC (1984) Field evidence of compass orientation in migrating juvenile grunts (Haemulidae). J Exp Mar Biol Ecol 81:181-192

Randall JE (1983) Red Sea reef fishes. Immel, London

Randall JE (1994) Twenty-two new records of fishes from the Red Sea. Fauna Saudi Arabia 14:259-275

Randall JE (1995) Coastal fishes of Oman. University of Hawaii Press, Honolulu

Randall JE, Anderson RC (1993) Annotated checklist of the epipelagic and shore fishes of the Maldive Islands. Ichthyol Bull JLB Smith Inst Ichthyol 59:1-47

Reese ES (1977) Coevolution of corals and coral feeding fishes of the family Chaetodontidae. Proc 3rd Int Coral Reef Symp $1: 267-274$

Riegl B, Velimirov B (1991) How many damaged corals in the Red Sea reef systems? A quantitative survey. Hydrobiologia 216/217:249-256

Righton D, Kemp J, Ormond R (1996) Biogeography, community structure and diversity of Red Sea and western Indian Ocean butterflyfishes. J Mar Biol Assoc UK 76:223-228

Righton D, Miller M, Ormond R (1998) Correlates of territory size in the butterflyfish Chaetodon austriacus (Rüppel). J Exp Mar Biol Ecol 226:183-193

Rilov G, Benayahu Y (1998) Vertical artificial structures as an alternative habitat for coral reef fishes in disturbed areas. Mar Environ Res 45:431-451

Rilov G Benayahu Y (2000) Fish assemblages on natural versus vertical artificial reefs: the rehabilitation perspective. Mar Biol 136:931-942

Risk MJ (1972) Fish diversity on a coral reef in the Virgin Islands. Atoll Res Bull 153:1-6

Roberts CM, Ormond RFG (1987) Habitat complexity and coral reef fish diversity and abundance on Red Sea fringing reefs. Mar Ecol Prog Ser 41:1-8

Roberts CM, Ormond RFG, Shepherd ARD (1988) The usefulness of butterflyfishes as environmental indicators on coral reefs. Proc 6th Int Coral Reef Symp 2:331-336

Roberts CM, Shepherd ARD, Ormond RFG (1992) Large-scale variation in assemblage structure of Red Sea butterflyfishes and angelfishes. J Biogeogr 19:239-250

Roblee MB, Ziemann JC (1984) Diel variation in the fish fauna of a tropical seagrass feeding ground. Bull Mar Sci 34:335-345

Rossier O, Kulbicki M (2000) A comparison of fish assemblages from two types of algal beds and coral reefs in the south-west lagoon of New Caledonia. Cybium 24(1):3-26

Sale PF (1980) The ecology of fishes on coral reefs. Oceanogr Mar Biol Annu Rev 18:367-421

Salita JT (2001) The influence of spatial arrangement of seagrasses on fish abundance in Bolinao, northern Philippines. ZMT Contributions 10, Centre for Tropical Marine Ecology, Bremen

Schraut G (1995) Dokumentation, Zonierung und ökologische Untersuchungen der Ichthyofauna eines Riffabschnittes im nördlichen Roten Meer bei Sharm El Sheikh (südl. Sinai, Ägypten). Diploma thesis, University of Marburg, Germany

Sheppard CRC (1998) Biodiversity patterns in Indian Ocean corals, and effect of taxonomic error in data. Biodivers Conserv $7: 847-868$
Sheppard CRC, Sheppard ALS (1991) Corals and coral communities of Arabia. Fauna Saudi Arabia 12:3-170

Sheppard C, Price A, Roberts C (1992) Marine ecology of the Arabian Region. Academic Press, London

Smith MM, Heemstra PC (1991) Smith's sea fishes. Southern Book Publishers, Johannesburg, South Africa

Souter DW, Lindén O (2000) The health and future of coral reef systems. Ocean Coast Manage 43:657-688

StatSoft (1997) Statistica for Windows 5.1. StatSoft, Tulsa, Okla.

Talbot FH, Goldman B (1972) A preliminary report on the diversity and feeding relationships of the reef fishes of One Tree Island, Great Barrier Reef System. In: Proceedings of a symposium on corals and coral reefs, 1969. Marine Biological Association of India, Kerala, India, pp 425-443

Thollot P (1992) Importance of mangroves for Pacific reef fish species, myth or reality? Proc 7th Int Coral Reef Symp 2:934-941

Thompson AA, Mapstone BD (1997) Observer effects and training in underwater visual surveys of reef fishes. Mar Ecol Prog Ser 154:53-63

Thresher RE (1991) Geographic variability in the ecology of coral reef fishes: evidence, evolution, and possible implications. In: Sale PF (ed) The ecology of fishes on coral reefs. Academic Press, San Diego, pp 401-436

Tortonese E (1983) List of fishes observed near Jeddah (Saudi Arabia). J Fac Mar Sci Jeddah 3:105-110

UNEP/IUCN (1988) Coral reefs of the world. UNEP Regional Seas Directories and Bibliographies. IUCN, Gland, Switzerland and Cambridge, UK/UNEP, Nairobi, Kenya

Vine PJ, Vine MP (1980) Ecology of Sudanese coral reefs with particular reference to reef morphology and distribution of fishes. In: Proceedings of a symposium on the coastal and marine environment of the Red Sea, Gulf of Aden, and Tropical Western Indian Ocean, vol 1. Khartoum, Sudan, pp 88-140

Wahbeh MI (1981) Distribution, biomass, biometry and some associated fauna of the seagrass community in the Jordan Gulf of Aqaba. Proc 4th Int Coral Reef Symp 2:453-459

Wahbeh MI, Ajiad A (1985a) Reproductive biology and growth of the goatfish, Parupeneus barberinus (Lacepede), from Aqaba, Jordan. J Fish Biol 26:583-590

Wahbeh MI, Ajiad A (1985b) The food and feeding habits of the goatfish, Parupeneus barberinus (Lacepede), from Aqaba, Jordan. J Fish Biol 27:147-154

Walker DI, Ormond RFG (1982) Coral death from sewage and phosphate pollution at Aqaba, Red Sea. Mar Pollut Bull 13:21-25

Weinstein MP, Heck, KL (1979) Ichthyofauna of seagrass meadows along the Caribbean coast of Panama and in the Gulf of Mexico: composition, structure and community ecology. Mar Biol 50:97-107

Williams DMcB (1991) Patterns and processes in the distribution of coral reef fishes. In: Sale PF (ed) The ecology of fishes on coral reefs. Academic Press, San Diego, pp 437-474

Williams DMcB, Hatcher AI (1983) Structure of fish communities on outer slopes of inshore, mid-shelf and outer shelf reefs of the Great Barrier Reef. Mar Ecol Prog Ser 10:239-250

Winterbottom R (1985) Revision of the congrogadid Haliophis (Pisces:Perciformes), with the description of a new species from Indonesia, and comments on the endemic fish fauna of the northern Red Sea. Can J Zool 63:209-217

Winterbottom R, Anderson RC (1997) A revised checklist of the epipelagic and shore fishes of the Chagos Archipelago, Central Indian Ocean. Ichthyol Bull JLB Smith Inst Ichthyol 66:1-28

Wrathall TJ, Roberts CM, Ormond RFG (1992) Territoriality in the butterflyfish Chaetodon austriacus. Environ Biol Fish 34:305-308 